A Dissertation

presented to

the Faculty of the Graduate School

at the University of Missouri-Columbia

In Partial Fulfillment

of the Requirements for the Degree

Doctor of Philosophy

by

CHRISTOPHER S. KINDLE

Dr. Wendy Sims, Dissertation Supervisor

May 2019 
The undersigned, appointed by the dean of the Graduate School, have examined the dissertation titled

\section{CHARACTERISTICS OF THE HIGH SCHOOL VARSITY MIXED SHOW CHOIR}

presented by Christopher S. Kindle,

a candidate for the degree of doctor of philosophy,

and hereby certify that, in their opinion, it is worthy of acceptance.

\section{Dr. Wendy Sims}

\section{Dr. Brian Silvey}

Dr. Brandon Boyd

Dr. Carol Gilles 


\section{ACKNOWLEDGEMENTS}

I would like to begin by thanking my advisor, Dr. Wendy Sims. You are an amazing teacher, researcher and mentor. Without your support, guidance and cheerleading through this doctoral process none of this would have been possible. Thank you for helping my passion be put down on paper.

I would also like to express my sincere gratitude to my committee members, Dr. Brian Silvey, Dr. Brandon Boyd and Dr. Carol Gilles. Thank you for being willing to serve on this committee and help guide me to a better understanding of not just music education research, but research in general.

Sincere shout-out to Dr. Brian and Cecily Lanier. Without your constant support I would not be the musician and educator that I am today. Thank you for always believing in not just me, but in my ability as a musician and teacher.

Finally, thank you to my family and friends. My most heartfelt thanks to my parents, Patti and Ken Markwell and Greg and Lisa Kindle. Thank you for always supporting my ideas/decisions and being willing to help in anyway. Thank you for always reminding me to keep reaching for the stars. I thank each of you for sticking by my side and pushing me to achieve the goal/dream that I set out to complete. None of this would be possible without your constant love and support. 
TABLE OF CONTENTS

ACKNOWLEDGEMENTS --_-

LIST OF TABLES -

ABSTRACT -- - vii

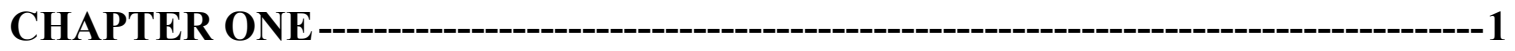

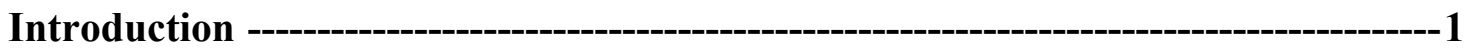

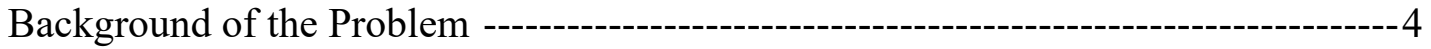

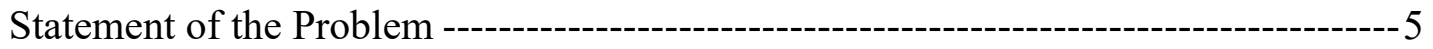

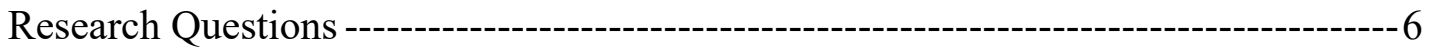

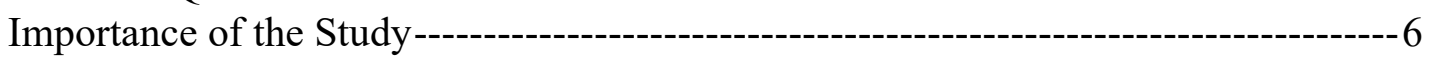

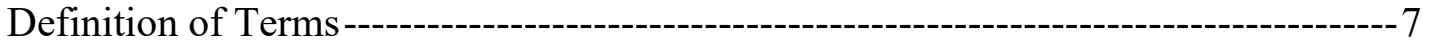

CHAPTER TWO

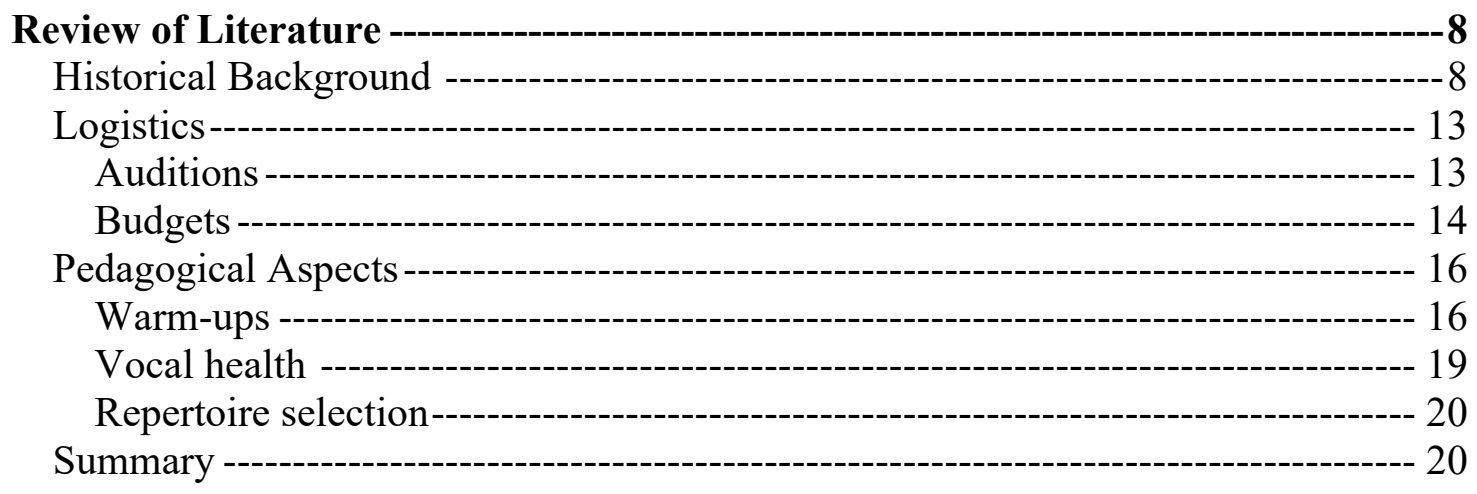

CHAPTER THREE ---_--_-- 22

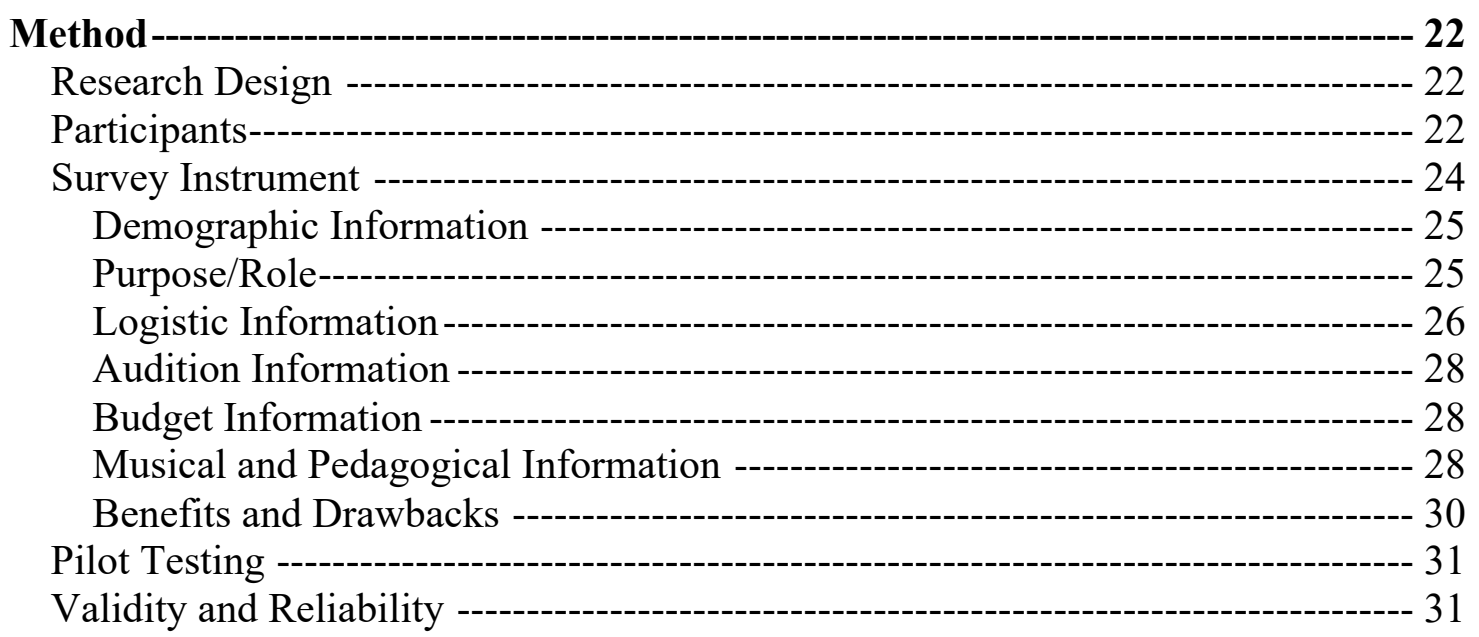




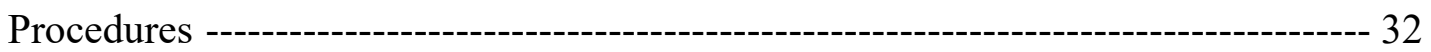

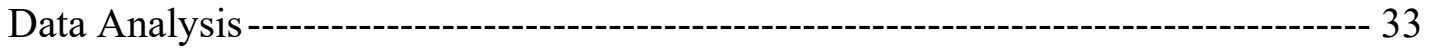

CHAPTER FOUR --_-- 34

Results --- 34

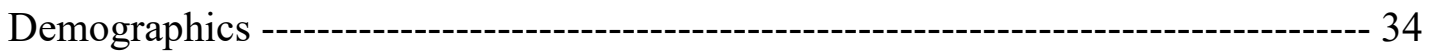

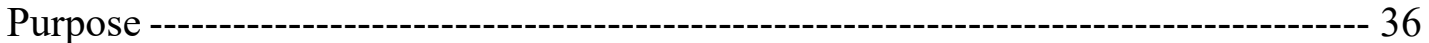

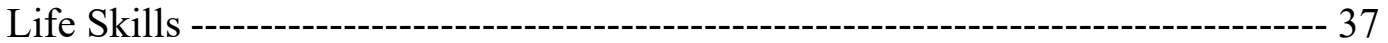

Teamwork------------------------------------------------------------------------------------ 38

Challenging ------------------------------------------------------------------------ 38

Confidence Building--------------------------------------------------------------- 39

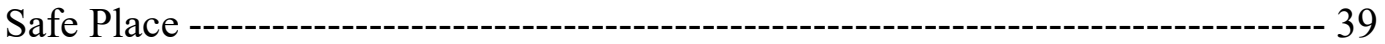

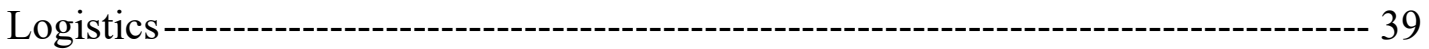

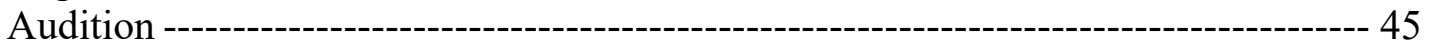

Budget --------------------------------------------------------------------------------- 46

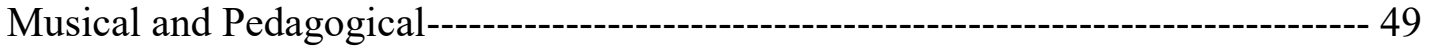

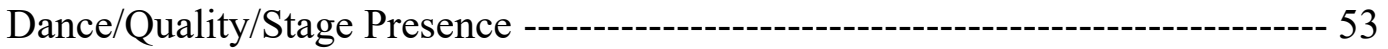

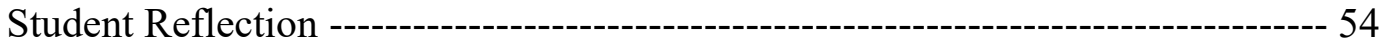

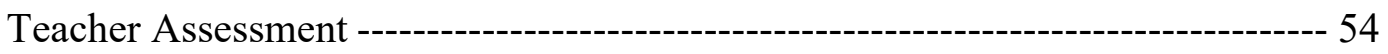

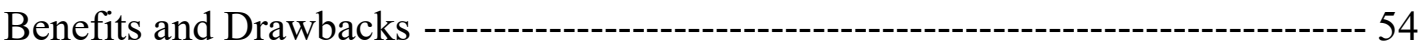

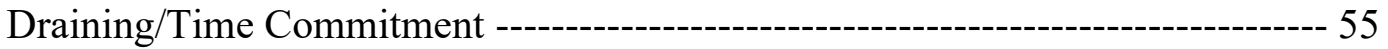

More Popular than Concert Choir ------------------------------------------------ 56

Expense------------------------------------------------------------------------- 56

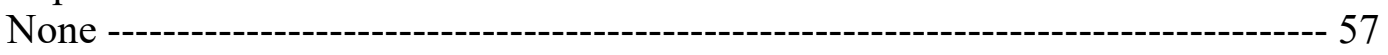

Dance Takes Away from Singing------------------------------------------------- 57

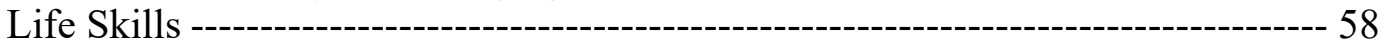

Performing ------------------------------------------------------------------------------------- 58

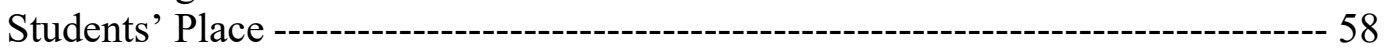

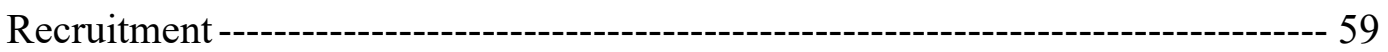

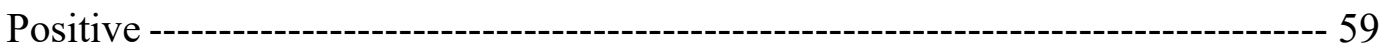

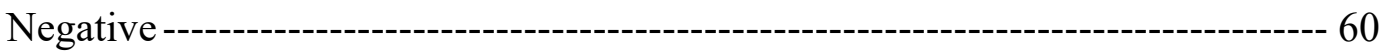

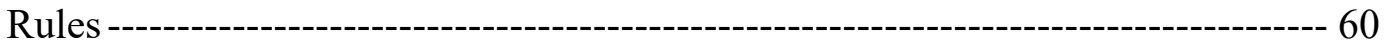

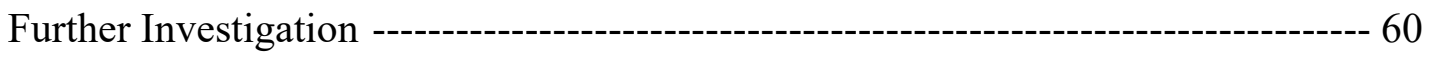

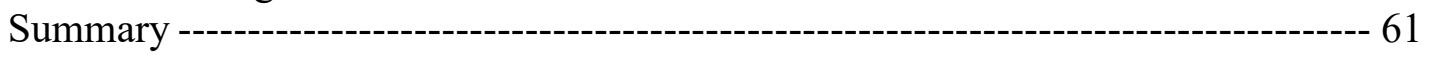

CHAPTER FIVE -- 64

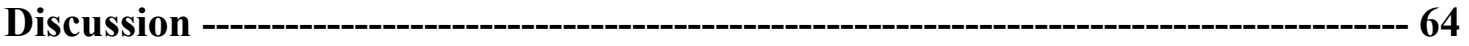

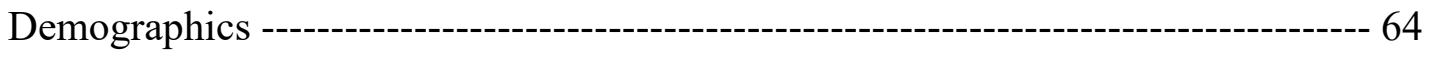

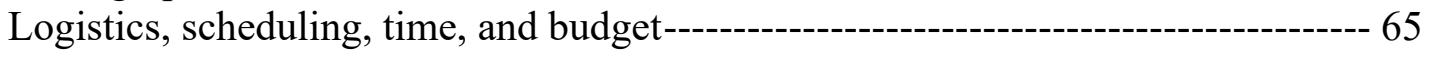

Musical/pedagogical, student selection, and rehearsal/performance

practices/activities --------------------------------------------------------------- 68

Purpose, benefits and drawbacks --------------------------------------------- 72

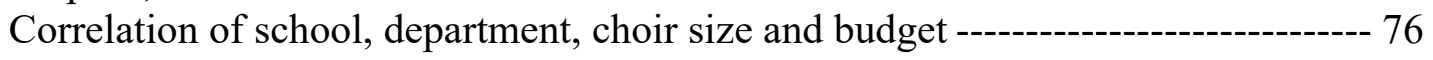

Implications---------- 77 


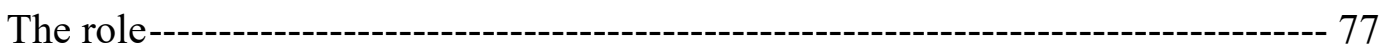

Logistics----------------------------------------------------------------------------------------- 78

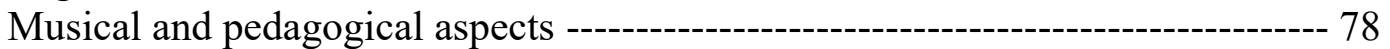

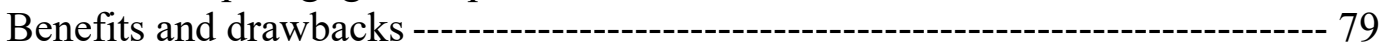

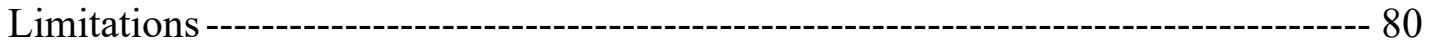

Additional Suggestions for Research------------------------------------------------------- 80

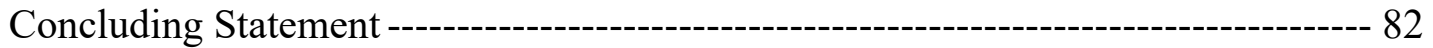

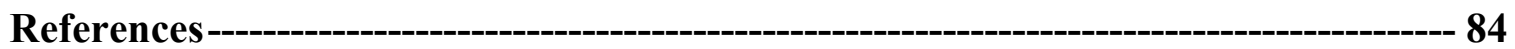

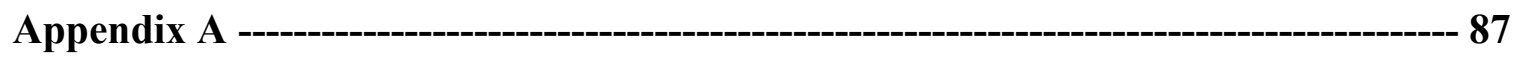

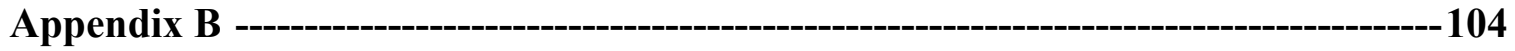

Appendix C ------------------------------------------------------------------------------------------105

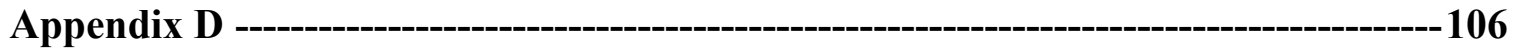

Appendix $\mathrm{E}$ -

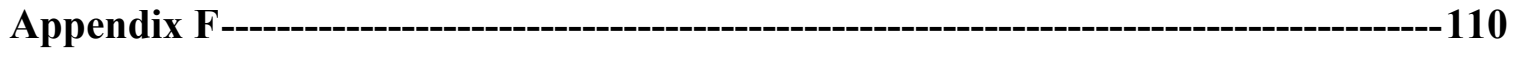

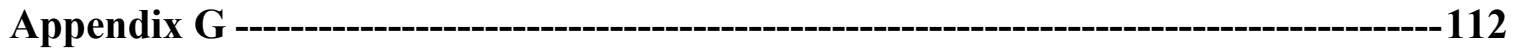

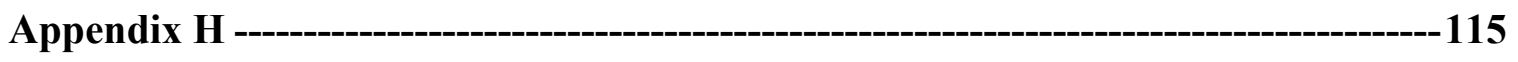

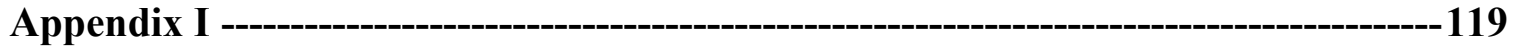

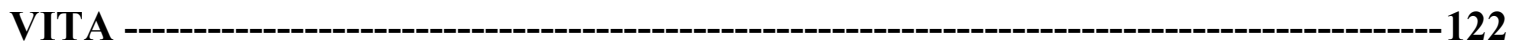




\section{LIST OF TABLES}

Table 1 Frequencies and Percentages of Participants' ACDA Division -------------------- 35

Table 2 Frequencies and Percentages of Number of Show Choirs Directed-------------- 35

Table 3 Frequencies and Percentages of Responses to the Purpose/Role of the Show

Choir

Table 4 Frequencies and Percentages of Show Choir's Relationship with Concert Choir

Table 5 Frequencies and Percentages for Credit or Extracurricular Class -------------- 41

Table 6 Frequencies and Percentages of Extra Rehearsals Before and/or After School 42

Table 7 Frequencies and Percentages for Who the Choreographers Were --------------- 43

Table 8 Frequencies and Percentages for Who Performed in the Live Band ------------- 44

Table 9 Frequencies and Percentages of Band Rehearsal Times with Singers ----------- 44

Table 10 Frequencies and Percentages of Audition Process ------------------------------- 46

Table 11 Frequencies and Percentages of Opportunities to Particiapte in Fundraisers 48

Table 12 What is the total number of singers in the choral department?------------------ 49

Table 13 How many singers of each voice part in the varsity show choir? -------------- 50

Table 14 Frequencies and Percentages of Items Practiced During Rehearsal ----------- 51

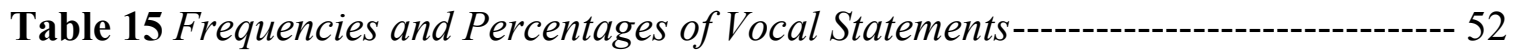

Table 16 Frequenceis and Percentages of Vocal Assessments for Proper Vocal

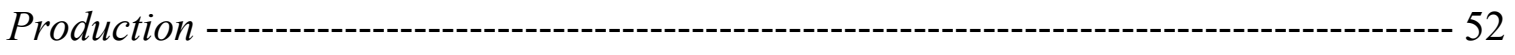

Table 17 Frequencies and Percentages of Vocal Assessments to Check Vocal Parts --- 53

Table 18 Frequencies and Percentages of Responses to Potential Drawbacks----------- 55 


\title{
CHARACTERISTICS OF THE HIGH SCHOOL VARSITY MIXED SHOW CHOIR
}

Christopher S. Kindle

\author{
Dr. Wendy Sims, Dissertation Supervisor
}

\begin{abstract}
This descriptive study was designed to provide researchers and educators with baseline data about characteristics of show choirs and information regarding the role the show choir plays in the high school choral department. Seventy directors of varsity mixed show choirs across the nation responded to a researcher-constructed survey designed to examine the role, logistics, musical and pedagogical characteristics and potential benefits and drawbacks of these ensembles. Results indicated that the participants believed that the purpose of the show choir was to make sure that students are receiving a wellrounded choral experience by exposing them to different musical genres, while allowing for the inclusion of multiple disciplines like dance, band and theatre. Data indicated the considerable amounts of time and money expended on this ensemble. The results showed that the directors taught proper vocal technique and that the students were learning about the basics of singing even while being exposed to pop, rock and Broadway style music. Participants indicated that through the show choir, the students were learning more than just music. This includes life skills that they can use not only while in school but also once they graduate, such as how to be a part of a team and how to present themselves in front of an audience. The biggest drawbacks reported were time commitments for the director and ensemble. The findings of this study provide educational reasons in support of the role the show choir plays in the choral curriculum, while the logistical data could
\end{abstract}


serve as a baseline against which teachers, administrators and school districts might compare their own programs with a national sample of responses. 


\section{CHAPTER ONE}

\section{Introduction}

The term show choir tends to either excite directors or make them cringe. There are directors who embrace show choir and there are directors who do not. In support of the show choir, Shaw and Thomas (2005) stated, "As we embark on this new journey, those out in the trenches must be engaged in meaningful dialogue and work together to bring equitable recognition of this type of choral music education in the American Choral Directors Association" (p. 109). I am a strong advocate for implementing show choirs in schools across the nation. Not only was I in a show choir in high school, but I also had the privilege of participating in a show choir in college. I am a former director and a current choreographer, clinician and adjudicator of show choirs. Needless to say, when I came out of college ready to teach, my background in show choir was stronger than that of most new choral directors. However, where do these fresh-out-of-college directors and even veteran directors turn to figure out the purpose, curriculum, and logistical needs for a show choir?

Show choir is an ever-evolving art form that has taken off throughout the nation since the 1960's for colleges and the 1970's for high schools (Jennings, 2017; Weaver \& Hart, 2011). The existence of show choirs in high school, and even some university choral departments, continues to maintain popularity across the country (Lanier, 2007). There is no comprehensive national data available about how many schools offer show choirs, however, based on the National Center for Education Statistics (NCES) reports of school offerings. The NCES uses the coding system, School Courses for the Exchange of 
Data (SCED), to code the specific courses. SCED is a "voluntary, common classification system for prior-to-secondary and secondary school courses"

(https://nces.ed.gov/forum/index.asp). This system has the choral offerings classified into four different categories. Chorus is defined as:

Chorus courses develop students' vocal skills within the context of a large choral ensemble in which they perform a variety of styles of repertoire. These courses are designed to develop students' vocal techniques and their ability to sing parts and include experiences in creating and responding to music (https://nces.ed.gov/forum/sced_resources.asp).

Another course is Vocal Ensemble, described as:

Vocal Ensemble courses help students develop vocal techniques and refine their ability to sing parts in small ensembles (e.g., madrigal, barber shop, gospel).

Course goals may include helping students develop their solo singing ability and emphasize one or several ensemble literature styles. These ensembles may include both instrumental and vocal music and include experiences in creating and responding to music.

Individual Technique - Vocal Music is included, defined as:

Individual Technique-Vocal Music courses provide instruction in and encourage the refinement of vocal techniques and repertoire other than the ability to sing in groups. These courses may be conducted individually or in small groups. Formal and informal performances may be part of the instructional program as well as experiences in creating and responding to music. 
The newest course that was added into the current version, which is version 6.0 , is Contemporary Vocal Ensemble. According to the description:

Contemporary Vocal Ensemble courses help students develop vocal techniques while focusing primarily on contemporary stage literature styles, such as traditional jazz, jazz improvisation, and rock. These courses may also focus on gospel, show choir, or barbershop choral group dynamics. The ensembles provide performance opportunities and include experiences in creating and responding to music.

Although most show choirs would fall into this last category, there is no way to disaggregate the data for just one type of ensemble.

Ever since television shows like Glee and America's Got Talent became popular, show choirs have become more prevalent. This is evident from school performances, community outreach performances, school-hosted and state competitions, and even national competitions involving show choirs. From swing choirs of the past to modern choirs of today, having a show choir in a school's choral department can enhance the school's activities program (Dollins, 2011). However, attempts to find research about show choirs reveal that there is very little research out there for directors and administrators to use for information or advocacy.

There are many different ideas on what a show choir should be used for (Shaw \& Thomas, 2005). There are high schools that solely use their show choir for community outreach, schools that have a show choir that is more competitive than any of their sports teams, and schools that use their show choir for both community outreach and competitions, but also in conjunction with their traditional choir. In the end, decisions 
may come down to how much time, support and commitment the school, director, students, parents and community are willing to put in. Many questions have to be answered in order for the decision to be made on whether or not a school wishes to offer a show choir.

In an effort to assist by providing information that may be useful to decision makers, this research investigation is designed to contribute to the understanding of the role of the show choir in the high school choral department. Additional goals are to provide data related to the logistics and the characteristics of the musical and pedagogical aspects of the high school show choir.

\section{Background of the Problem}

For beginning or veteran teachers who have not directed a show choir but take a new position where this is an expectation, or who wish to start a show choir in their choral department, there is limited information and a multitude of uncertainties

surrounding information regarding these ensembles (Thomas, 2006). Stated by Thomas (2006), "Many choral directors have expressed the desire and hesitation to begin a show choir, often because they simply do not know how to do so" (p. 45). There are teachers who are trying to teach or are expected to teach a show choir, but who do not have enough information in order to feel successful at this aspect of their job (Alder \& Mulvihill, 2016). Choral music teacher education students may only have experienced concert choirs in their own performing experiences in secondary school and college, and for most of these music educators there was little to no instruction provided in regards to movement in choral performance during their teacher preparation program (Hylton, 1987). Music educators, though, have the duty to provide our students with more than 
one musical approach and to present them with a variety of styles (Mack, 2011). In fact, the educational community has come to the realization that providing students with a wide range of experiences to meet their diverse interests actually enhances the whole educational enterprise for them (Shaw \& Thomas, 2005). Stated by Thomas (2006), “Any college or university offering a degree in choral music education will provide method courses; however, it is uncertain how much instructional time is spent on the 'how to' of directing a show choir" (p. 45). Teachers have to rely either on personal experiences that they had in high school, learning about what has been done in the past at the school, or from other busy colleagues (Alder \& Mulvihill, 2016; Mack, 2011). Research is not available for these young teachers to figure out what the role of the show choir is or should be in the high school setting. They would benefit from research that helps them understand budgeting, the time commitment, and other efforts that go into having and developing a show choir. As show choirs gain popularity within public schools at a time when schools are facing economic challenges, there is a need for music educators to have resources available to assist them with understanding the many educational and logistical aspects of show choir (Alder, 2012).

\section{Statement of the Problem}

This research study is based on the assumption that there are multiple aspects that go into making a show choir successful. Not every high school choral department is of the same size, has the same resources, expectations, or other attributes. Teachers should be informed as to what they are undertaking when they take over, develop, or make decisions about a show choir program. This investigation was designed to contribute to the understanding of what the role of the show choir is or should be in the high school 
choral department, the logistics of a show choir program, musical and pedagogical characteristics, and potential benefits and drawbacks to a show choir program. Current show choir directors could also benefit from this information as they seek to evaluate or advocate for their programs.

\section{Research Questions}

Four primary questions guided my work:

1. What characterizes the high school show choir with respect to logistics, including scheduling, time, and budget?

2. What characterizes the musical and pedagogical aspects of the high school show choir, including student selection and participation, rehearsal and performance practices, performance activities, choral/vocal pedagogy?

3. According to high school choral directors, what are the purposes, benefits, and drawbacks of having show choir(s) in the choral department?

4. What are the relationships (if any) between school size, choral department size, ensemble size and budget?

\section{Importance of the Study}

Quite a bit of time, effort, and money are being devoted to show choirs by teachers, students, and schools, yet very little is known about these ensembles from a data-based perspective. This investigation will contribute to expanding the knowledge regarding this type of ensemble, specifically by adding information about the role and characteristics of the show choir in the high school choral setting. Ideally, this information will serve to help music educators to better understand the role of the show choir in the high school choral department. The information provided may assist teachers 
with data they can use to start programs, compare with to evaluate their current programs, and/or use to advocate for new or existing programs.

\section{Definition of Terms}

The following terms and definitions were used in this study. I adapted these terms and definitions from those used by authors of related literature.

1. Director is the teacher of the show choir. This person usually designs the show with the choreographer and rehearses the group.

2. Choreographer is the person that creates and teaches the stage movement to the show choir. This person may also be known as the visual director.

3. Choreography is the stage movement that is set to the music. Different styles are used depending on the choreographer.

4. Combo is a band accompanying the show choir.

5. Show Choir is a singing group that performs popular or Broadway literature. Dancing is choreographed for this group and singers usually wear some form of costuming. There are also, usually, different heights used in the choreography whether on platforms or other objects such as props, to create levels.

6. Swing Choir is a singing group that is a mix of show choir and jazz choir that incorporates jazz charts into their set. This group rarely uses platforms and mainly uses straight lines and few formations. 


\section{CHAPTER TWO}

\section{Review of Literature}

This study was intended to help music educators understand the role of the show choir in the secondary school choral department. High school show choir directors from around the nation were invited to participate in a survey designed to address various characteristics of their show choir programs.

I completed an extensive search for research literature on this topic. I utilized The Choral Journal, Google Scholar, JSTOR, ProQuest Dissertations and Thesis, Sage, and bibliographies from the dissertation, theses and articles that I found. No articles about show choirs were found in research journals. Only two doctoral dissertations were available, one of which provided data useable for this research (Alder, 2012). Three master's theses were available, providing data that was useful for this research (Cassidy, 2013; Jennings, 2017; Johnson, 2004). The remaining sources for this literature review were practitioner-oriented, pedagogical books and articles.

This review of literature is organized into three main categories: (a) historical background, (b) logistics, and (c) pedagogical aspects of show choirs. Authors of existing literature have touched the surface of these aspects. However, there is little literature reporting details such as the cost of running a show choir for the school and the students, the amount of time put into the show choir, how auditions are conducted, what type of literature is truly being used, how the director focuses on vocal pedagogy, and so forth.

\section{Historical Background}

The beginning of the art form that is now called show choir can date back to the early days of Fred Waring (Alder, 2012; Alder \& Mulvihill, 2016; Fredrickson, 2004; 
Jennings, 2017; Weaver \& Hart, 2011). Waring started with a group of all-male instrumentalists who also sang. This group became the Waring's Pennsylvanians in 1917 (Weaver \& Hart, 2011). As explained by Weaver and Hart (2011), "It was one of the first musical ensembles in American history to embrace and entertain the trendy and entertaining tunes of the day. Folk music, love songs, patriotic hymns, and Broadway showstoppers- - his group sang it all.” (p.13) After this group became a success Waring decided to allow women into the group, and he also added a full singing chorus. He renamed the group Fred Waring and the Pennsylvanians (Weaver \& Hart, 2011).

Once this musical craze started to take over, the music started moving from playing on the radio to the television in different variety shows. Directors at some high schools started to use popular music in their classrooms. The evolution of popular-music choirs really began in college and university groups, however, which came into the spotlight in the early 1950's (Fredrickson, 2004). George Krueger was the first person to create a pop-focused glee club at Indiana University, called the Singing Hoosiers (Weaver \& Hart, 2011). This is also when the first swing choirs began. Directors started to experiment with the idea of using more popular music in the classroom. These new groups received criticism from different music educator associations, reflecting the views of traditional choral directors who were resistant to change and saw these choirs as a threat to classical music (Weaver \& Hart, 2011). However, more and more show choirs were starting to develop across the nation. The Young Americans from Corona, California, called themselves "America's Oldest Show Choir," as they introduced the west coast to this genre (Weaver \& Hart, 2011). Then, in Indiana in 1964, the Ball State Singers started by Donald Neuen came into prominence. This seems to be a catalyst for 
show choirs, as more and more directors started to implement popular music into their curriculum (Weaver \& Hart, 2011).

Within all of the historical information, there is no mention of what the groups were spending on costumes, choreography or music. These choirs were singing pop tunes or show tunes, but there is little research to examine whether these students were still getting the traditional choral experience in addition to their show experience. This leads me to question whether the directors were using these groups as a recruitment tool to get students interested in their concert choirs. Johnson (2004) stated, however, "There has not been much research completed on the effects of show choirs on the enrollment in choral programs." Johnson was interested in the male enrollment and found that choral programs that had a show choir had the same average male enrollment as choral programs that did not have a show choir (Johnson, 2004). More importantly, though, Johnson did find a statistical difference for choral programs that had a competitive show choir. Those programs had a male enrollment of 5.6\% compared to choral programs with non-competitive show choirs, which had a male enrollment of 2.8\% (Johnson, 2004).

Once these choirs started to gain ground not just in colleges, but also in high schools, show choir competitions started to be developed. The competitions are believed to have begun in 1975, when a small Catholic high school in Indiana, Bishop Luers High School, was recognized for creating the first competition exclusively for swing choirs (Weaver \& Hart, 2011). Although not every director may believe in the idea of competing, there are no reasons provided in the literature regarding why directors may want to compete or not compete. A question that arises is whether attitudes might be related to music educators' philosophy about the main role or purpose of this type of 
ensemble. It would be interesting to discover the perceptions of directors regarding competitions.

It is accepted that the term choir no longer means a group of singers that performs only serious music (Fredrickson, 2004). However, for many years there were no documents or standards that directors could use as a guide that pertained specifically to show choirs. All that was available were the National MENC standards that that pertained to more traditional choirs. In 1998, dialogue about drafting show choir standards began to take place between choir directors and the American Choral Directors Association's National Repertoire \& Standards (R\&S) Chair for Jazz and Show Choir (Spradling, 2001). This dialogue continued through the summers of 1999 and 2000 at the sites of Show Choir Camps of America, where directors would meet with the R\&S Chair and hear updates, provide information and come together around the movement for standards (Spradling, 2001). The first version of these new standards was completed in 2001. The original authors were Diana R. Spradling and the National R\&S Jazz \& Show Choir Committee (American Choral Directors Association, 2018). This committee used the Music Educators National Conference (MENC) Standards of Excellence as their model for the Show Choir Standards (Spradling, 2001). These new standards included a definition of what a show choir was, a statement of purpose, premises and ten standards. In 2006, Ken Thomas and the National R\&S Show Choir Committee revised the standards into their current iteration (American Choral Directors Association, 2018). The current standards document is organized into three parts: Purpose, Premise and Standards. 


\section{According to the American Choral Director's Association}

(https://archives.acda.org/page.asp?page=showchoirstandards):

The purpose of these standards is to provide choral directors and choral educators (choreographers, arrangers, set designers, costumers, etc.) with a foundation upon which to build their show choirs as a viable and contributing part of a total choral program.

The purpose statement also includes recommendations for how the standards might be used as starting points, goals, or measures of evaluation for beginning, developing, or experienced choirs.

The premise of the standards is that the show choir should not replace or take over from the traditional choral program, but that it should enhance the existing program. The premise states (https://archives.acda.org/page.asp?page=showchoirstandards):

The show choir experience is designed to build upon the experiences of a traditional choral program, to provide opportunities for the exploration of additional literature, to expose more people to experiences in choral singing and to attract more listeners to the beauty and joy of choral music.

It is the responsibility of the choral director/educator to promote a level of excellence with the performance of all choral music in relation to the style of the pieces and the period in which it was written.

The standards are divided into 10 categories: singing, movement/dance, instrumental accompaniment, integrating art forms, interpreting music elements, stylistic awareness, performance practices and evaluation, creativity of the individual, entertainment art and history and pop culture. The standards appear on the site of the 
American Choral Directors Association, available at:

https://archives.acda.org/page.asp?page=showchoirstandards.

\section{Logistics}

The organization and management of show choirs is quite complex. Some of the logistics include budgets, auditions of vocalists and band members, determining eligible grade levels, whether the show choir is curricular or extra-curricular, choreography, and music selection. The logistical aspects discussed in the literature focus primarily on the auditions and budgets, and many of the other issues are not addressed.

Auditions. Auditions are an important part of the show choir process. Most directors do not just allow the students to merely sign-up for the class. With a competitive show choir, especially, students must be adequately prepared and able to be a contributing factor for the whole group. Authors have tried to explain how to audition and different directors have their own ideas of what works best for their group. Within this literature arises the problem that directors have not been asked how they have students audition for the band.

The information that is available regarding auditions is primarily advice from expert authors writing about show choirs, but not research-based. For example, in the book, Putting the Show in Choir, Mack (2011) provided pointers for the person that is auditioning and for the panel of judges. Some of the tips for performers are no excuses about allergies, remain positive, act professional and thank your accompanist. Mack (2011) also had advice for the teachers, such as not postponing the posting of final results, videotaping the auditions, and having the students audition with a verse and chorus from a ballad as well as from an up-tempo selection. 
Cassidy (2013) also discussed some ideas for directors on how to hold auditions. He suggested that if they are held in large groups, there should be a preliminary round of auditions. He advised the director to take into consideration how the audience will perceive the performer. Cassidy also recommended that the director check the range of the singers, and that they perform a song with which they are familiar. According to Thomas (2006), the vocal audition should evaluate the singer in multiple ways.

Strategies for running vocal auditions were also provided by Alder and Mulvihill (2016). They stated that the director and panel need to ask themselves these questions:

1. Does the person singing have a generally pleasing voice that the layman could enjoy?

2. Would I want to hear more from him or her?

3. Does the singer appear to be at ease and comfortable as a performer?

4. Does the singer make me feel comfortable and at ease as an audience member? (p. 37)

These authors also discussed the dance audition. According to Alder and Mulvihill (2016), a choir that sings well is "just a choir," so it is important to have the choreography audition so that there can be good choreography to go along with the singing. They recommend that the audition does not have to be too intensive, but it should reflect the type of program that will be performed.

Budgets. Budgets for show choirs are used for a variety of purposes. Some researchers have tried to explore the specific monetary needs of the show choir including music, competition fees, transportation, and student fees (Alder \& Mulvihill 2016). Authors Alder and Mulvihill (2016), discussed the musical arrangements that were being 
used. They explained that show choirs sometimes cannot just rely on stock arrangements. Depending on what the show is going to be, the director usually has to look into having custom arrangements created for their show. If the director decides to use custom arrangements, the cost becomes greater because they are not only paying an arranger, but also for copyright fees. What these authors did not discuss, though, is how this will affect the budget.

In some programs, in order to offset the cost of the show choir, enrolled students, and sometimes all students (including students that are part of the band or stage crew that do not actually take it as a class), will be charged a "pay to play" fee similar to the fees athletic departments charge their students (Cassidy 2013; Dollins, 2011; Mack, 2011). The expenses of show choir in one particular school in Indiana were analyzed (Alder \& Mulvihill, 2016). It was interesting to see that in this situation each member of every choir had to pay a membership fee of $\$ 250$ just to support the show choir. Then depending on the level of the group into which they auditioned and placed, they were also required to pay a group fee, ranging from $\$ 250$ to $\$ 500$. What was interesting about this was that the students could raise the funds for this fee via fundraisers organized by either the choral department or booster club. Additionally, the students were charged a major trip fee, which was normally around $\$ 1,000$. Other fees included polo shirt, overnight stays and bus transportation (Alder \& Mulvihill, 2016).

Those data were just for one school in Indiana, so information is needed about student expenses to participate in show choirs in other schools, to determine how typical this may or may not be. Based on this one example, questions arise as to what other schools across the nation are charging the students to be a part of the group. There is no 
other literature describing the financial resources needed to operate a show choir. Show choir directors may need to buy music, pay a choreographer, purchase costumes and possibly pay for set pieces to be made or instrumentalists to play, but these types of costs have not been documented.

This is the extent of the information available. This literature provides some ideas as to what to do in an audition, however, there is no actual data to show how the directors are holding the auditions and who the directors are auditioning. The literature gives us information about one particular school, including the fees that members must pay, but there is no other data available about what schools are spending for music, choreographers or even costumers. This leads me to infer that there is much more information about logistics that needs to be addressed to help directors and school administrators understand the financial commitments being made to provide a show choir experience to their students.

\section{Pedagogical Aspects}

Literature has provided more information about pedagogical aspects of show choir than logistical. This includes discussions about warm-ups, vocal health and repertoire selection. Even though there is more information about the pedagogical aspects, there is still information missing, leaving many potential questions unanswered.

Warm-ups. As with a traditional choir, it is important for show choir members to warm-up before they sing. Warm-ups in a show choir setting should follow the same pedagogical goals as used in a traditional choir. There should be three main elements to show choir warm-ups: physical, mental and repertoire (Webb, 2007). Physical warm-ups are especially vital for show choir members to prepare their bodies not only for singing, 
but also for dancing. Some of the dances can be very intense and the muscles need stretching beforehand in order to prevent injury. It has been stated that singers should really think of themselves as "vocal athletes" (Webb, 2007). There is no way that a marathon runner would run a race without stretching (Webb, 2007). Glover (2001) suggested that the director should use proper kinesthetic warm-ups that will help the show choir member's engagement in healthy vocal technique. These techniques will help with breathing, posture and even tone. Singers should be doing stretching exercises for the neck, shoulders, arms, back and abdominal muscles because this vitalizes the singer, and this is also an indirect way to establish the correct singing posture nonverbally. Stretching techniques used with the show choir can also transfer over to the traditional choir, and some of the same warm-ups used in the traditional choir can be used in the show choir. Some examples of warm-ups provided by Pomfret (2012) include:

- Humming - to get rid of jaw tension

- Gentle sirens or sighs - emphasizing gradual movement

- Lip or tongue trills - activating muscles of breathing and coordination of breath with the tone

- Light five-note scales or triads on variety of vowels - muscles of support and those in the throat to work together (p. 61-62)

The mental aspect of singing should also be considered when preparing voices to sing. The singers must mentally prepare to portray the character of the music. Young singers have a tendency to sing or perform without truly thinking about what they are singing or performing (Webb, 2007). Show choir members have to think about not only what they are singing, but also what character they are portraying and what movement is 
coming next. According to Mack (2011), an excellent mental exercise that also works for breathing is the ratio exercise. She explains that this is an ideal exercise because it gets the blood flowing through the body and it recharges the mind. This warm-up will help get the members focused on what they are about to do. By doing the mental warm-ups, it will also allow the members to focus on not just the character and what they are about to perform, but also on the vocal technique that they should be using. By using these mental warm-ups, the show choir member can learn to listen to the members around them to help create the balance and blend (Glover, 2001).

Show choir directors and members should also take advantage of repertoire-based warm-ups, which are warm-ups that reflect the ideal singing style of the repertoire. The warm-ups have contributed to creating beautiful, resonant tones; however, the members also need to perform tasks that will occur in the repertoire (Pomfret, 2012). By using repertoire warm-ups, the director is showing the singers that the warm-ups really do apply to the music they are singing (Webb 2007). The skills that the singer learns through the warm-ups should be easily transferred into the repertoire, which in the end will make for more musical productivity, and the singers will have greater enjoyment in making the music (Glover, 2001). Because show choirs perform mostly pop/rock songs, it is important for directors to consider this style when choosing warm-ups. This will help singers better understand the music and prepare them for performance, while ensuring that the singers are not mimicking an unhealthy pop-music vocal style or trying to sound like the recording artist and not use their proper choral voice. Just like in traditional choir settings, the show choir repertoire warm-up should be custom-made to address the tricky concepts that will be present in the rehearsal (Glover, 2001). 
Vocal health. When it comes to singing technique, both traditional and pop/rock pieces should be approached with equal regard to vocal health. Students have a tendency to watch YouTube and want to imitate the original artist when dealing with show choir. It is the director's job to teach the difference in the way that the song selection is going to be performed. The key word here is the term choir. According to Lanier (2007), it is up to the director to teach the singers to use a healthy vibrant choral tone. He suggests that the director is going to have to help model the desired technique. Not just for show choirs, but also for any choir, excellent pitch and intonation are always important traits (Lanier, 2007). This leads me to infer that if good vocal technique is taught to all choirs, then it should transfer and apply to all vocal ensembles. More than likely, many students are going to sing in multiple ensembles. Because in show choirs the students are dancing as they sing, they must remain keenly aware of their vocal production.

As with traditional choir, it may be beneficial for show choir directors to listen to their singers individually to assess their progress and address any vocal faults (Spurgeon, 2004). Other ways that the director can assess a show choir is by videoing them as they sing. Assessing the students is an important way to see if they are holding up their part of the team. According to Cassidy (2013), at times a director should take out the dancing and have the students just sing - then video them singing and dancing. This is an effective way for the director to assess the members, but also for the members to assess themselves and the ensemble. They can then hold each other accountable for what they are doing as a group and take some ownership of the ensemble. Cassidy (2013) provided other specific ways that directors can assess their students in order to check that fundamental vocal technique is being utilized. 
Repertoire selection. There is a wide range of quality represented in the show choir music that is available for purchase today, just like with all choral music (Hylton, 1987). Mack (2011) suggested that the directors have to know where they want the show to go. Does the show follow a theme or is it a compilation of songs? Just like with a traditional choir, the director needs to be creative. The director should look for variety in styles, tempos, lyrics and challenges (Mack, 2011). Overall, the music that is chosen should be high quality and be very well arranged (Fredrickson, 2004).

Choral directors must choose music that their choir can sing successfully. Some directors prefer to wait and see how the group sounds together in order to get a feel for the type of music that they will be successful at performing (Dollins, 2011). The directors need to know what the limitations of the choir are and what the possibilities of the choir are. Directors have to be honest when looking for and choosing music. They need to be truthful to themselves and to the choir and pick music that will work for their choir (Lanier, 2007). Mack (2011) suggests that the director has to remember that their choir not only be able to sing with a healthy technique, but also if it is basic, simple and not interesting then your students and audience are going to lose interest fast.

\section{Summary}

The existing literature on show choirs in the United States has focused mainly on the history of show choirs, touched on how to hold auditions, skimmed the surface of budgets, and discussed warm-ups, vocal health and repertoire. Research is needed to determine what the purpose of the show choir is and all of the inner workings of show choirs across the nation. After reviewing the literature and the ACDA Standards, there are gaps in the information about show choirs that need to be filled, not just for teachers, 
but also for administrators. Information about what the cost is for schools to have a show choir, where these resources are coming from, and what the individual students are paying is important. Understanding how the audition process work with singers and, in some cases, combo members, would be informative. Vocal pedagogy information including warm-ups and vocal health is necessary to make sure that the students are singing properly no matter what the style of repertoire. Learning about the type of repertoire being used for the show choir would be informative. These are just some of the aspects about which data is lacking. The number of students and teachers engaged with show choir ensembles warrants deeper investigation into this performing ensemble, to get a closer look at what goes on behind the scenes so that individuals involved can be as informed as possible about the type of commitment it takes to offer this opportunity to high school students. 


\section{CHAPTER THREE}

\section{Method}

The purpose of this study is to contribute to the understanding of what role the show choir plays in the high school choral department. This study was designed to investigate the logistics of show choir programs, the musical and pedagogical aspects, and the benefits and drawbacks to having a show choir program. Because there is little research involving show choirs specifically, an investigation to gather baseline data seemed warranted. This study was intended to help choral directors and music educators in general understand the role of this unique type of ensemble in the choral department.

\section{Research Design}

This research study was descriptive, consisting of an author-designed survey instrument. An online, electronic survey was utilized in order to gather information from a large population spread across the United States (Fink, 2009). I chose to use an electronic survey so that I could reach a large number of directors and receive a quick response. The surveys were distributed through Qualtrics, online survey software provided by the University of Missouri (Qualtrics Lab, Inc., 2018). This software allowed the collected data to be downloaded into a database for analysis.

\section{Participants}

The purpose of this study focused on the varsity mixed show choir of high school choral departments. In order to achieve a good representative overview of what the role of the show choir played; I chose to use participants from around the United States that directed the varsity mixed show choir at their school. The participants were contacted through the Facebook group Show Choir Connect. The survey was also offered to 
directors that were not a part of the website via the consent form, which permitted participants to send the survey to other directors or to send them my contact information, using a variation of the snowball technique of acquiring additional participants.

The online survey opened to participants in two different time windows, which ranged over a four-month period. The first installment was sent out on May 1 and lasted until May 15. A reminder was sent out as a post on the Facebook page on May 7. The survey software did not track individual responses to preserve participant privacy, every member of the Facebook page received the reminder. Because these dates were at the end of the school year, the survey was reopened again on June 22 and remained open until early August, allowing teachers who didn't get the chance to participate an opportunity to again be a part of this survey. For the second round of the survey, reminders were not sent out.

A total of 70 individuals met the criteria (high school varsity show choir director) and completed enough of the survey to be considered participants. Given that 14 directors that were not members of the group also contacted me directly to ask if they could participate in the survey, the remaining 56 responses are assumed to have been generated from the Facebook posts. Although this group included approximately 1,600 members at the time of the study, is not possible to calculate a response rate for this survey, because group membership includes not only directors of all levels, middle school through college, but also "show choreographers, show designers, arrangers, clinicians, judges, and more" (https://www.facebook.com/groups/showchoirconnect/). Detailed demographic data to describe the respondents will be provided in Chapter 4. 


\section{Survey Instrument}

This descriptive study examined the role of the show choir in the choral department of high schools across the United States using a survey designed for this study. The survey instrument items were created based on (a) information from the preexisting literature about the role of the show choir (b) recommendations from vocal music teachers and PhD students that participated in the pilot tests and (d) my own years of experience as a show choir director, choreographer and adjudicator. Qualtrics online survey software was used to distribute the survey to the participants and compile the data.

The participants were asked to only consider their varsity mixed show choir. The reason for limiting the selection to just the varsity show choir was because some directors have multiple show choirs such as single-gender, junior varsity, or middle school. Typically, each show choir has a different budget, and there were questions that pertained specifically to whether their show choir doubles as their concert choir.

I divided the survey into seven sections that contained quantitative questions using closed/guided responses (see Appendix A for the complete survey). The first section was designed to collect the participant's demographic information. The other six sections were designed to answer the following research questions:

1. What characterizes the high school show choir with respect to logistics, including scheduling, time, and budget?

2. What characterizes the musical and pedagogical aspects of the high school show choir, including student selection and participation, rehearsal and performance practices, performance activities, choral/vocal pedagogy? 
3. According to high school choral directors, what are the purposes, benefits, and drawbacks of having show choir(s) in the choral department?

4. What are the relationships (if any) between school size, choral department size, ensemble size and budget?

Demographic Information. The first section of the survey was designed to collect demographic and general information about the participants. The first question asked them to identify their gender, to determine the representation of genders among the respondents. The participants were also asked to identify how many years they had been teaching, to find out how diverse the representation of experience was among the participants. They were also asked to respond with approximately how many students were in the school and how many were in the choral department, because school size and choral department size could be a factor in aspects of show choir such as choir size or budget.

Because this survey was sent out across the United States, the next question asked to which American Choral Directors Association (ACDA) region the participant belonged. ACDA has divided the United States into seven geographic regions (American Choral Directors Association, 2018). This question was intended to ensure that there was a representation of directors of show choirs from across the country. To get an idea of the types of experiences these teachers were encountering in their schools, participants were asked whether they started the show choir or if it was already established when they started teaching the choir, and how many show choirs they directed at their school.

Purpose/Role. Section two was designed to answer the first part of research question 3 regarding purposes and drawbacks. I thought that in order to answer the later 
questions about the role of the show choir in the choral department, answering this information first would help prepare the participants to focus/define their responses to the later questions. In these questions, participants provided information about to what extent they agreed with statements provided relating to the purposes/roles of the show choir, including competitions, community outreach, providing students the chance to perform a variety of musical styles while incorporating other disciplines like dance, band and theatre, recruiting and making sure students have a well-rounded choral experience.

At the end of this section, the participant had the chance to write in any other purpose(s) that the show choir served. This was an important component so that the participants had a chance to voice their opinions in further detail or explain more in-depth answers to the questions, and potentially provide ideas other directors could consider regarding their own show choir.

Logistic Information. The third section was designed to answer the first part of research question 1 related to logistics, and aspects of research question 2 regarding musical and pedagogical aspects of the high school show choir. In this section, participants provided information about the grade levels of students permitted to participate in the varsity show choir, whether the varsity show choir was a unique ensemble or if it doubled as the concert choir, and if the students were required to participate in concert choir in order to be a part of the show choir. Curricular and rehearsal issues were addressed in questions regarding whether the show choir was a forcredit or an extra-curricular class, if it met during the school day or before/after school day, and if the show choir met during the day, were there also extra rehearsals before/after school. 
For the next part of this section the participants provided information about how they obtained their musical arrangements and who normally choreographed their shows. This question allowed them to provide a percentage for each type arrangement including stock arrangements, show packages, custom arrangements or teacher arrangements. This section also allowed the participant to provide other information if they used a different kind of arrangement. The participants were asked to provide information about who normally choreographs for their varsity show choir. The participants could choose as many responses as applied, selecting from among students, teacher, hired professional or parent, or they choose other and further explain who choreographed for their group.

In the last part of this section, participants provided information about their use of a live band. If the participant answered that no live band was used, they were skipped to the end of this section. Participants that responded yes to this question were asked to provide information on about band members auditions, whether membership was all students or if adults were involved, and whether the band rehearsed with the singers during the school day or before/after school hours.

Participants then were asked how many performances were given during the school year for the categories of competitions, school, community, or other, with a space to explain. This information gives insights into the amount of time, besides just rehearing, that is spent on the show choir.

The participants were asked to provide percentages that totaled $100 \%$ for the categories of high school sponsored, college sponsored, state association sponsored, or amusement park sponsored competitions, or other, with a space to explain. This information provides information about where the show choir is competing. 
Audition Information. Section four was designed to continue to answer research question 2. Participants were asked to specify how the students audition for the show choir. They were asked if the students had to perform a singing audition as well as a dancing audition, and if the students auditioned alone, in groups such as a quartet or larger, or both individually and in a group.

Budget Information. The fifth section of the survey was designed to complete research question 1 related to costs associated with the choir. Participants were asked was about their allotted budget for the year, and how that budget was funded. They were given multiple options of funding sources from which to choose, including school district, student membership fees, booster organizations, business sponsors and student fundraisers. The participants had the chance to write in and explain other options at the end of this question.

The second part of this section asked the participants to indicate whether each student paid a fee to be a part of the show choir, and if so, how much. They were then asked if the students had fundraising opportunities to offset the fee. and whether the students were required to participate in the fundraisers

Next, the participants were asked for information on how their budget was spent. They were asked to fill in the percentage of the budget spent on music, choreography, costumes, props, travel and paid musicians. They also had the opportunity to provide other expenditures at the end of this question or clarify if one of the answers was not provided, so that the percentages provided would add up to $100 \%$.

Musical and Pedagogical Information. Section six of the survey was designed to finish answering research question 2. Within this section, the participants were asked 
to provide information about the total number of singers in the department, and how the voicing was divided among soprano, alto, tenor and bass.

This part of the survey also posed questions designed to examine vocal pedagogy. Participants were asked how many minutes were used on different types of warm-ups, including physical, mental and repertoire. The participants, again, were given a text box in which to explain other warm-ups as well as the length of time they spent on the warmups to prepare the singers.

The survey was then designed to ask participants what style of music they included in their repertoire. The participants were asked to provide percentages that added up to $100 \%$ for the musical styles of classical, pop, rock, Broadway, jazz, or other, with a space to explain. This information would show, stylistically, what is being taught in the show choirs around the United States.

Participants were asked to what extent the various items were practiced during a rehearsal, using a 5-point Likert-type scale ranging from all rehearsals to never. The participants were asked to provide these answers to the categories of music reading, vocal fundamentals, proper vocal singing, uniform vowels, diction, pitch and intonation, and proper breath support and breathing. This section was designed to disclose what choral and vocal pedagogical items are being taught in the varsity show choir.

The next part of this section was designed to gain an understanding of the participant's ideas on whether different vocal techniques were addressed depending on the musical selection, and if beautiful choral tone was the end goal of the ensemble. The participants were asked to what extent they agreed; from strongly agree to strongly 
disagree, using a 5-point Likert-type scale. This would provide additional information to address the choral and vocal pedagogical part of this research question.

The last part of section six asked the participants to provide information about vocal assessments; whether students were assessed on proper vocal production and on their vocal part. This information will again show whether vocal pedagogy is being taught in the show choir. The participants were asked how often each of these items was tested.

Benefits and Drawbacks. The last section, section seven, was designed to finish answering research question 3 . This question was place at the end to wrap up the survey. Given that the survey started with the purpose of the show choir, I thought that after providing all of the other responses, the participants would be in an appropriate frame of mind to consider the benefits and drawbacks of this type of ensemble. The participants were asked to use a 5-point Likert-type scale to rate the extent to which they agreed with the statements: show choirs are too time consuming, the price of the show choir results in students who are not able to participate, and the choreography makes it difficult to keep the focus on proper singing. This section of questioning will help see if participants felt that these items are drawbacks to having a show choir.

The last questions in this section allowed for the participant to share their thoughts and opinions. There were two open-response questions in which participants could describe drawbacks and benefits that they had experienced with their show choir, or issues that could be perceived as potential drawbacks and benefits. 


\section{Pilot Testing}

This survey was sent out two separate times as a pilot. The first pilot testing was by vocal music teachers who were the assistants to the main director, as well as retired music teachers that had taught a show choir. None of these individuals was eligible to participate in the actual survey administration but had sufficiently relevant experiences to be able to provide feedback related primarily to content. Five individuals responded to this pilot study. The web address was sent to the pilot participants and they were asked to complete the survey and report back the length of time it took them, and any suggestions they might have to clarify any of the questions.

The second pilot study was sent out to a doctoral seminar class with eight students responding. This group consisted of only one vocal music teacher and the remaining seven were band, orchestra or general music educators. Their main purpose was to provide feedback related to technical and research-related issues. They were asked to take the survey and report how long it took them to take it and to make suggestions on ways to clarify wording.

Revisions were made based on the feedback received from both groups of pilot study participants. The main revision was using the term "varsity mixed" show choir as opposed to "top mixed" show choir, which had been used in the original version. It also was suggested that a completion percentage bar be added to the survey so the participants could judge how much time it would take to finish the survey.

\section{Validity and Reliability}

Content validity of the survey instrument was established in two ways. First, the questions were based on the pre-existing literature on the subject. The second way was 
via the two pilot tests that were sent out. The participants in the first pilot tests were experienced professionals with extensive knowledge directing this type of ensemble. The participants in the second pilot test were experienced educators who had taken many surveys and also had taken coursework related to descriptive research.

There was no practical way to establish reliability using statistical procedures for this survey. However, because the study's participants completed the survey voluntarily, and they were guaranteed anonymity, there was no reason for the participants to be misleading with their responses.

\section{Procedures}

Prior to the distribution of the survey, the informed consent, recruitment letter and final draft of the survey instrument were submitted to the Internal Review Board (IRB) at the University of Missouri for approval. Once approval was received from the IRB, the documents were prepared for electronic distribution (see Appendix B). The informed consent notice (see Appendix C) was placed at the beginning of the survey, and respondents confirmed their informed consent by clicking to begin.

The invitation to participate in the survey was sent initially as a post on the Facebook page (see Appendix D). In the invitation, the purpose of the study, minimal risks involved, protection of personal information and a Uniform Resource Locator (URL) link to the survey were included. I used a social media merge function through Qualtrics in order to maximize the response rate. This also reduced non-show choir directors from receiving this invitation. 


\section{Data Analysis}

Using descriptive statistics such as frequencies, percentages, means and standard deviations, I summarized the data collected from the closed-response questions. The online survey program, Qualtrics, provided calculations for some of the item responses, but the information provided was limited for interpreting the results of the study. I therefore exported data into a Microsoft Excel spreadsheet to generate means, frequencies and standard deviations for each of the closed-response survey items. For each of the Likert-type scale item questions I calculated percentages for the respondent's choices. For items where the respondents were asked to write in a numerical response, I calculated range, means, standard deviations and response frequencies. Respondents did have the opportunity on some closed-response items to enter an answer other than the ones I had supplied, and I categorized these text responses to include with the data reported for those items.

For survey items that were open-ended questions, I analyzed these responses by assigning codes, combining those codes into themes and displaying the data in table form (Creswell, 2007). In order to establish reliability, a colleague who held a doctorate in music education and was an experienced music education researcher reviewed the responses to these five open-ended items. I provided this person with the responses and a list of codes that had emerged from my analysis. He then assigned codes from the list provided and was invited to suggest additional codes if necessary. Our percentages of agreement were $95 \%$ after comparing the assigned codes, with no codes added or changed. We discussed any coding differences until we reached 100\% agreement. 


\section{CHAPTER FOUR}

\section{Results}

The purpose of this study was to provide educators and researchers with an understanding of the role show choirs play in the high school choral department through the investigation of logistics, musical and pedagogical aspects and the benefits and drawbacks of a show choir program. Directors of show choirs were invited to participate in the study on the Facebook page, Show Choir Connect, and through email for those directors without Facebook. Seventy show choir directors $(N=70)$ completed the survey, but the number of responses to individual items may range from 57-70, because all participants did not answer all of the questions.

\section{Demographics}

The first section of the survey was designed to collect demographic and general information about the participants. It consisted of six items.

In survey item 1, respondents indicated their gender. The majority of the respondents were male $(n=46,66 \%$; females, $n=24,34 \%)$. In survey item 2 , the respondents were asked how many years they had been teaching, counting the current year as year 1 . The range was 3 years to 38 years with the average equal to 16.26 years $(S D=8.3)$. The respondents were then asked approximately how many students attended the school in which they taught. The responses ranged from 180 to 9,000 students with an average of $1,406.94$ students $(S D=1258.8)$. Survey item 4 asked the respondents which American Choral Director Association Division they represented. The respondents represented six of the seven divisions, with the majority of the respondents from the 
Southwestern $(n=23,32.86 \%)$ and the North Central $(n=22,31.43 \%)$ divisions (see

Table 1).

Table 1

Frequencies and Percentages of Participants' ACDA Divisions

\begin{tabular}{lcr}
\hline ACDA Division & Response Frequency & $\%$ \\
\hline Southwestern & 23 & 32.86 \\
North Central & 22 & 31.43 \\
Central & 17 & 24.29 \\
Southern & 3 & 4.29 \\
Western & 3 & 4.29 \\
Eastern & 2 & 2.86 \\
Northwestern & 0 & 0 \\
Total & 70 & 100.02 \\
\hline
\end{tabular}

Note: Total is not equal to $100 \%$ due to rounding.

The last two items in this section asked if the director began the show choir program or if it was already established, and how many show choirs the participant actually directed. The majority of the directors took over a program that was already established ( $n=59,84 \%)$ while only a few directors began the program $(n=11,16 \%)$. Most of the participants direct either one show choir $(n=24,34.29 \%)$ or two show choirs $(n=29,41.43 \%)$. Very few direct four or more show choirs $(n=5,7.14 \%)$ (see Table 2$)$.

Table 2

Frequencies and Percentages of Number of Show Choirs Directed

\begin{tabular}{lcr}
\hline Number of Choirs & Frequency & $\%$ \\
\hline 1 & 24 & 34.29 \\
2 & 29 & 41.43 \\
3 & 12 & 17.14 \\
$4+$ & 5 & 7.14 \\
Total & 70 & 100 \\
\hline
\end{tabular}




\section{Purpose}

This section of the survey was developed to gain information about the purpose of the show choir, in order to answer part of Research Question 3: "According to high school choral directors, what are the purposes, benefits, and drawbacks of having show choir(s) in the choral department?"

Item 7 included a 5-point Likert-type scale with statements centered on the purpose, or role, of the show choir. Respondents indicated the extent of their agreement on a scale from Strongly Agree to Strongly Disagree. Most of the directors strongly agreed or somewhat agreed with the statements that were provided (see Table 3).

Table 3

Frequencies and Percentages of Responses to the Purpose/Role of the Show Choir

\begin{tabular}{|c|c|c|c|c|c|c|}
\hline Statements & $\begin{array}{l}\text { Strongly } \\
\text { Agree }\end{array}$ & $\begin{array}{l}\text { Somewhat } \\
\text { Agree }\end{array}$ & $\begin{array}{l}\text { Neither } \\
\text { Agree or } \\
\text { Disagree }\end{array}$ & $\begin{array}{l}\text { Somewhat } \\
\text { Disagree }\end{array}$ & $\begin{array}{l}\text { Strongly } \\
\text { Disagree }\end{array}$ & $N$ \\
\hline $\begin{array}{l}\text { A main purpose/role of the show } \\
\text { choir is to provide the students a } \\
\text { chance to perform a variety of } \\
\text { musical styles and incorporate } \\
\text { multiple disciplines like dance, } \\
\text { band and theatre. }\end{array}$ & $\begin{array}{c}58 \\
(83 \%)\end{array}$ & $\begin{array}{c}11 \\
(16 \%)\end{array}$ & $\begin{array}{c}0 \\
(0 \%)\end{array}$ & $\begin{array}{c}0 \\
(0 \%)\end{array}$ & $\begin{array}{c}1 \\
(1 \%)\end{array}$ & 70 \\
\hline $\begin{array}{l}\text { Show choir allows students to have } \\
\text { a well- rounded choral experience. }\end{array}$ & $\begin{array}{c}40 \\
(58 \%)\end{array}$ & $\begin{array}{c}23 \\
(33 \%)\end{array}$ & $\begin{array}{c}4 \\
(6 \%)\end{array}$ & $\begin{array}{c}1 \\
(1 \%)\end{array}$ & $\begin{array}{c}1 \\
(1 \%)\end{array}$ & $69 *$ \\
\hline $\begin{array}{l}\text { The show choir is the main } \\
\text { recruitment tool for the choral } \\
\text { department. }\end{array}$ & $\begin{array}{c}\mathbf{3 7} \\
(\mathbf{5 3 \%})\end{array}$ & $\begin{array}{c}22 \\
(31 \%)\end{array}$ & $\begin{array}{c}6 \\
(9 \%)\end{array}$ & $\begin{array}{c}4 \\
(6 \%)\end{array}$ & $\begin{array}{c}1 \\
(1 \%)\end{array}$ & 70 \\
\hline $\begin{array}{l}\text { A main purpose/role of the show } \\
\text { choir is for competitions. }\end{array}$ & $\begin{array}{c}8 \\
(11 \%)\end{array}$ & $\begin{array}{c}36 \\
(51 \%)\end{array}$ & $\begin{array}{c}6 \\
(9 \%)\end{array}$ & $\begin{array}{c}14 \\
(20 \%)\end{array}$ & $\begin{array}{c}6 \\
(9 \%)\end{array}$ & 70 \\
\hline $\begin{array}{l}\text { A main purpose/role of the show } \\
\text { choir is for community outreach. }\end{array}$ & $\begin{array}{c}11 \\
(16 \%)\end{array}$ & $\begin{array}{c}34 \\
(49 \%)\end{array}$ & $\begin{array}{c}13 \\
(19 \%)\end{array}$ & $\begin{array}{c}11 \\
(16 \%)\end{array}$ & $\begin{array}{c}1 \\
(1 \%)\end{array}$ & 70 \\
\hline
\end{tabular}

Note: The most frequent response to each statement appears in bold type. *One participant did not respond to this item.

All but one of the participants $(n=69,99 \%)$ selected strongly agree or somewhat agree with the statement, "A main purpose/role of the show choir was to provide the 
students a chance to perform a variety of musical styles and incorporate multiple disciplines like dance, band and theatre." Ninety-one percent $(n=63)$ of the respondents agreed with the statement, "Show choir allows students to have a well- rounded choral experience." Only 2 respondents (2\%) disagreed this with this statement. Most of the respondents agreed $(n=59,84 \%)$ with the statement, "The show choir is the main recruitment tool for the choral department," while only 5 (7\%) disagreed. Although $62 \%$ selected strongly agree or somewhat agree with the statement, "A main purpose/role of the show choir is for competitions," a total of $29 \%$ selected somewhat disagree or strongly disagree. Sixty-five percent agreed with the statement, "A main purpose/role of the show choir is for community outreach," while 19\% neither agreed nor disagreed and $17 \%$ disagreed.

Item 8 was an open-ended question that allowed the respondents to type in their response. The respondents were asked, "Please identify any other purpose(s) you believe show choir serves." I assigned codes to the 30 responses to this open-ended question; however, some comments were applicable to more than one theme; so they were counted in each relevant category so the total exceeds the 30 comments made (see Appendix E for all responses). Based on the codes, I categorized them into themes. The emergent themes for item 8 included: (a) life skills $(n=13)$, (b) teamwork $(n=11)$, (c) challenging $(n=7)$, (d) confidence building $(n=5)$, and (e) safe place $(n=4)$. Each theme will be discussed in the paragraphs that follow.

Life Skills. There were thirteen responses that fit into this theme. Many of the responses including life skills overlapped with one of the other themes. Responses were coded into this category when they mentioned a term relating to group member, or with 
terms such as responsibility and social skills. One respondent stated, "To help raise students to be well rounded students - and a member of a community that depends on them. To teach responsibility and accountability." Another one of the respondents stated, "Teaches students about hard work, teamwork, and social skills that will aide them long into the future."

Teamwork. There were eleven responses that fit into this theme. Responses were coded into this category when they mentioned teamwork specifically, or when synonymous terms such as working with others were used. One of the respondents stated, "Teamwork and responsibility, also they learn how to follow a chain of command. My students learn how to problem solve also." Similar to that response, most of the participants tied teamwork in with other purposes. One respondent stated, "There is a huge psycho-social aspect of being in show choir that is similar to that of other team sports. The team atmosphere, group dynamic, goal-setting, winning and losing vs. beating or losing to self, responsibility of team before self, knowing when to lead and when to follow, and a host of other non-music related items that I believe are not only present but absolutely necessary in teaching as you go throughout the year."

Challenging. There were seven responses that fit into this theme. Responses were coded into this category when they mentioned the work challenging explicitly or with other terms such as demand or pushing limits. One of the respondents stated, "It is something that is challenging yet attainable and rewarding." Another respondent stated: The different style of performance is often a catalyst for pushing limits. The kind of effort required to put on a show choir performance has a level of physical and emotional demand that far exceeds anything else in the choral spectrum. 
Confidence Building. There were five responses that that fit into this code category, mentioning confidence specifically, or using similar terms such as poise and self-esteem. One respondent stated, "I use it as a way to teach presentation, carrying yourself with maturity and poise and discipline." Another respondent mixed confidence in with the other themes that were present. This respondent stated:

Teaches teamwork, mutual respect, performance skills, handling yourself in front of an audience, accelerated musical \& singing levels, fosters self-esteem. Builds many other integral skills such as confidence, self-discipline, accountability, working well under pressure, leadership, working in a team and more.

Safe Place. There were four responses that discussed how show choir could be a safe place for students. Responses were coded into this category when they mentioned safe place specifically, or when other terms such as home or sense of belonging were used. One respondent stated, "Show choir serves as a 'home' for the students involved to feel a sense of belonging in a safe place, and a group of similarly minded students who grow together." Another purpose a respondent stated was, "To provide students a tightknit community within a larger school community in which to belong."

\section{Logistics}

The third section of the survey was designed to answer the first part of Research Question 1: "What characterizes the high school show choir with respect to logistics, including scheduling, time...?" and part of Research Question 2: "What characterizes the musical and pedagogical aspects of the high school show choir, including student selection and participation...?" 
Item 9 asked the grade levels of the students who participated in the varsity show choir. A majority of the respondents $(n=54,78 \%)$ reported that the varsity show choir was made up of students in grades $9-12$. Fifteen $(22 \%)$ responded that the varsity show choir was made up of students in grades 10-12. One respondent chose other and stated that the varsity show choir included student from grades 7-12.

Item 10 was designed to determine if the show choir was also used as the concert choir for all or part of the year, or if it was separate from the concert choir. A majority of the respondents $(n=46,66 \%)$ indicated that the show choir was separate from the concert choir (see Table 4).

Table 4

Frequencies and Percentages of Show Choir's Relationship with Concert Choir

\begin{tabular}{lcr}
\hline Response & Frequency & $\%$ \\
\hline $\begin{array}{l}\text { Separate from the concert } \\
\text { choir }\end{array}$ & 46 & 66 \\
$\begin{array}{l}\text { Doubles as the concert } \\
\text { choir for the whole year }\end{array}$ & 19 & 37 \\
$\begin{array}{l}\text { Doubles as the concert } \\
\text { choir for part of the year }\end{array}$ & 5 & 7 \\
Total & 70 & 100 \\
\hline
\end{tabular}

Item 11 was designed to determine whether the students were required to also participate in concert choir if they wanted to participate in show choir. The respondents had to choose either yes, no or other. If they chose other, they were asked to explain their answer. Although $54 \%$ of the participants $(n=38)$ responded that students must participate in concert choir if they wished to be in show choir, $34 \%$ of the respondents $(n$ $=24$ ) responded that their students were not required to participate in concert choir. Eleven percent of the respondents $(n=8)$ responded other to the question and gave an explanation to their answer, such as, "With dual credit and advanced placement courses, 
many schools cannot require students to take more than one music elective." Another participant stated, "It is encouraged if their schedules allow room for two choirs."

To further examine the logistics of the show choir, items 12 and 13 of the survey were designed to see if the ensemble was a for-credit class that met during the school day or before/after school, or if it was an extra-curricular class that met during the day or before/after school. A majority of the respondents $(n=47,67.14 \%)$ responded that the show choir was a for-credit class that meets during the regular school day. However, $14.29 \%$ responded that the show choir was a for-credit class that meets before and/or after school, and $14.29 \%$ responded that the show choir was an extra-curricular class that meets before and/or after school. Only $4.29 \%$ responded that the show choir was an extra-curricular class that meets during the school day (see Table 5).

Table 5

Frequencies and Percentages for Credit or Extracurricular Class

\begin{tabular}{lcr}
\hline Response & Frequency & $\%$ \\
\hline $\begin{array}{l}\text { A for-credit class that meets } \\
\text { during the regular school } \\
\text { day }\end{array}$ & 47 & 67.14 \\
$\begin{array}{l}\text { A for-credit class that meets } \\
\text { before and/or after school }\end{array}$ & 10 & 14.29 \\
$\begin{array}{l}\text { An extracurricular class that } \\
\text { meets before and/or after } \\
\text { school }\end{array}$ & 10 & 14.29 \\
$\begin{array}{l}\text { An extracurricular class that } \\
\text { meets during the school } \\
\text { day }\end{array}$ & 3 & 4.29 \\
Total & 70 & 100.01 \\
\hline
\end{tabular}

Note: Total is not equal to $100 \%$ due to rounding.

Item 13 expanded on item 12 and asked if the choirs that meet during the school day had extra rehearsals before and/or after school. According to the participants that responded $(n=50)$, every choir had some extra rehearsals before and/or after school in 
addition to having regular class time during the school day. There were differences in how frequently these rehearsals were held, however (see Table 6).

Table 6

Frequencies and Percentages of Extra Rehearsals Before and/or After School

\begin{tabular}{lcr}
\hline Responses & Frequency & $\%$ \\
\hline Frequently & 24 & 48 \\
Often & 12 & 24 \\
Sometimes & 10 & 20 \\
Infrequently & 4 & 8 \\
Never & 0 & 0 \\
N/A & 0 & 0 \\
Total & 50 & 100 \\
\hline
\end{tabular}

To learn more about the logistics of the show choir with respect to the music performed, item 14 asked the respondents to indicate what approximate percentage were stock charts, show packages, custom arrangements, teacher arrangements and other. The data indicate that most directors have custom arrangements made for their show choir. Custom arrangements were used on average by $63.84 \%(S D=38.14)$ of directors, with a range of $0 \%$ to $100 \%$. Stock charts were used by an average of $20.86 \%(S D=30.87)$ schools, with a range of $0 \%$ to $100 \%$. Teacher arrangements averaged $14.2 \%(S D=$ 30.23 ) with a range of 0 to $100 \%$. With a range of $0 \%$ to $25 \%$, show packages averaged $0.78 \%(S D=3.6)$. One respondent chose the other option and reported creating arrangements for the choir.

Item 15 of the survey was designed to learn who is providing the choreography for the show choirs. Given that some show choirs use multiple choreographers, the respondents were able to choose all that applied. The data indicated that most of the respondents used a hired professional ( $n=67,68 \%$; see Table 7). Four respondents 
selected other and reported different options than what was listed, as included in the table.

Table 7

Frequencies and Percentages for Who the Choreographers Were

\begin{tabular}{lcr}
\hline Response & Frequency & $\%$ \\
\hline Hired Professional & 67 & 68 \\
Student & 15 & 15 \\
Teacher & 13 & 13 \\
Parent & 0 & 0 \\
Other & 4 & 4 \\
$\quad$ Graduated Alumni (3) & & \\
Total Amateur Choreographer (1) & 99 & 100 \\
\hline
\end{tabular}

Note: Participants selected all responses that applied.

Items 16 - 19, asked the respondents about the show choir band. Item 16

specifically asked the respondents if they used a live band. If the respondent answered No $(n=3,4 \%)$ the survey was set so that they skipped to the next section. If the respondent answered Yes $(n=67,96 \%)$ they continued with the questions about the ensemble. Item 17 of the survey asked if the students that were in the band were required to audition. The majority of participants $(n=43,66 \%)$ responded that students in the band had to audition, while ( $n=22,34 \%)$ responded that the students do not. Two of the respondents that responded Yes to a live band did not answer this question.

To further investigate the band, item 18 was designed in order to find out who participated in the band (see Table 8$)$. The majority of the respondents $(n=35,52 \%)$ responded that their show choir band was made up of mostly students with 1 or 2 nonstudent musicians. The response to "Non-students only" $(n=3,4 \%)$, was the lowest response along with other $(n=3,4 \%)$. The three who reported other wrote explanations 
including using their accompanist only, a mix of students and adults, and that depending on the year, adults would fill in where needed.

Table 8

Frequencies and Percentages for Who Performed in the Live Band

\begin{tabular}{lcr}
\hline Band Members & Frequency & $\%$ \\
\hline $\begin{array}{l}\text { Mostly Students (1 or 2 non- } \\
\text { student musicians) }\end{array}$ & 35 & 52.24 \\
Students Only & 18 & 26.87 \\
Mostly Non-Student & 8 & 11.94 \\
$\quad$ Musicians (1 or 2 student & & \\
musicians) & 3 & 4.48 \\
Non-Students Only & 3 & 4.48 \\
Other & & \\
$\quad$ Accompanist & & \\
$\quad$ adults of students and & & 100.01 \\
$\quad$ Depends on the year & 67 & \\
Total
\end{tabular}

Note: Total is not equal to $100 \%$ due to rounding.

The last item of this section was designed to learn how often the band rehearses with the singers during the school day and before and/or after school. The data, presented in Table 9, indicate that most bands never rehearse with the singers during the school day $(n=32,53 \%)$. The majority responded that the band rehearses with the singers before or after school for some rehearsals $(n=28,42 \%)$ or many rehearsals $(n=22,33 \%)$.

Table 9

Frequencies and Percentages of Band Rehearsal Times with Singers

\begin{tabular}{lcccccc}
\hline Rehearsals & $\begin{array}{c}\text { All } \\
\text { rehearsals }\end{array}$ & $\begin{array}{c}\text { Most } \\
\text { Rehearsals }\end{array}$ & $\begin{array}{c}\text { Many } \\
\text { Rehearsals }\end{array}$ & $\begin{array}{c}\text { Some } \\
\text { Rehearsals }\end{array}$ & Never & $N$ \\
\hline With the singers & 0 & 5 & 7 & 16 & $\mathbf{3 2}$ & 60 \\
during the day & $(0 \%)$ & $(8 \%)$ & $(12 \%)$ & $(27 \%)$ & $\mathbf{( 5 3 \% )}$ & \\
With the singers & 3 & 13 & 22 & $\mathbf{2 8}$ & 1 & 67 \\
before and/or after & $(5 \%)$ & $(19 \%)$ & $(33 \%)$ & $\mathbf{( 4 2 \% )}$ & $(1 \%)$ & \\
school & & & & & \\
\hline Note: The most frequent response to each statement appears in bold type. &
\end{tabular}


Item 27 asked the respondents how many performances were given in the categories of competitions, school, community and other (please explain). Competitions had the highest average number of performances $(M=5.86, S D=5.67$; range $=1 \%$ to $50 \%$ ). Community had the second highest average $(M=4.47, S D=5.63$; range $=0 \%$ to $40 \%)$. School performances had an average of $4.07(S D=3.41$; range $=0 \%$ to $20 \%)$ with not all respondents responding $(n=69)$. Respondents provided other examples such as elementary tours and exhibitions. This response had a very low number of performances, $(M=0.04, S D=0.2 ;$ range $=0 \%$ to $1 \%)$.

Survey item 28 was specific to the competitions that the respondents attended, asking them to indicate the approximate percentage of each competition type attended from among high school, college, state association, amusement park and other. High school sponsored competitions had the highest average participation, $(M=89.57 \%, S D=$ 17.94 ; range $=0 \%$ to $100 \%$ ). College sponsored competitions had an average of $5.47 \%$ $(S D=15.28$; range $=0 \%$ to $100 \%)$. With a range of $0 \%$ to $50 \%$, state association sponsored competitions had an average of $3.1 \%(S D=9.9)$. Participants gave other examples as well. These included Heart of America, FAME, community and national competitions. This response had an average of $1.26 \%(S D=4.23$; range $=0 \%$ to $20 \%)$. Amusement park sponsored competitions had the lowest average $(M=0.56, S D=3.29$; range $=0 \%$ to $25 \%)$ with not all respondents responding $(n=68)$.

\section{Audition}

Section four was designed to continue to answer Research Question 2 regarding musical and pedagogical aspects. In this section, respondents were asked how the students audition for the show choir. 
Item 20 of the survey asked the respondents to answer Yes or No to different types of auditions (see Table 10). 100\% $(n=70)$ of the respondents responded that the students must perform a singing audition. Almost every respondent $(n=67,96 \%)$ responded that the students also had a dance audition. Most of the respondents $(n=55$, $79 \%$ ) stated that the students audition both individually as well as in groups. A majority of the participants $(n=50,71 \%)$ responded that each student auditions individually, with most of the respondents ( $n=41,59 \%)$ indicating that the students did not audition in groups such as quartets or larger.

Table 10

Frequencies and Percentages of Audition Processes

\begin{tabular}{|c|c|c|c|}
\hline Audition & Yes & No & $N$ \\
\hline $\begin{array}{l}\text { Students must perform a singing audition to } \\
\text { be a part of the show choir }\end{array}$ & $\begin{array}{c}70 \\
(100 \%)\end{array}$ & $\begin{array}{c}0 \\
(0 \%)\end{array}$ & 70 \\
\hline $\begin{array}{l}\text { Students must perform a dancing audition to } \\
\text { be a part of the show choir }\end{array}$ & $\begin{array}{c}67 \\
(96 \%)\end{array}$ & $\begin{array}{c}3 \\
(4 \%)\end{array}$ & 70 \\
\hline $\begin{array}{l}\text { Students audition both individually and in } \\
\text { groups }\end{array}$ & $\begin{array}{c}55 \\
(79 \%)\end{array}$ & $\begin{array}{c}15 \\
(21 \%)\end{array}$ & 70 \\
\hline Each student auditions individually & $\begin{array}{c}50 \\
(71 \%)\end{array}$ & $\begin{array}{c}20 \\
(29 \%)\end{array}$ & 70 \\
\hline $\begin{array}{l}\text { Students audition in groups such as quartets } \\
\text { or larger }\end{array}$ & $\begin{array}{c}29 \\
(41 \%)\end{array}$ & $\begin{array}{c}41 \\
(59 \%)\end{array}$ & 70 \\
\hline
\end{tabular}

Note: The most frequent response to each statement appears in bold type.

\section{Budget}

The fifth section of the survey was designed to complete the answer to Research Question 1, regarding budget. Participants were asked a variety of questions to indicate how they paid for their varsity show choir and how their budget was spent.

Items 21 and 22 pertained to the budget and how it was funded. Item 21 asked the respondents to state what their total budget was for the year. The average of the budgets was $\$ 41,948(S D=48,283.72)$ with a range from $\$ 0$ to $\$ 300,000$. The median for this 
response was $\$ 30,000$, however, which provides a more accurate measure. Only 60 participants responded with dollar amounts, and one included the words "a lot" while another one responded, "I don't want to discuss."

To further examine the budget for the show choir, item 22 asked how the budget was funded. Respondents were asked what approximate percentage school/district, student membership fees, parent booster organization, business sponsorships, student fundraisers and other sources funded their budget. The average percentage of the budget provided by student membership fees was $33.56 \%(S D=29.02$; range $=0 \%$ to $100 \%)$. Student membership fees had the highest average of all of the entities. With a range of $0 \%$ to $100 \%$, parent booster organizations provided approximately $25.9 \%(S D=28.61)$ of the budget. Also, with a range of $0 \%$ to $100 \%$, the average for the school/district was $17.8 \%(S D=23.81)$. Student fundraisers almost matched the school/district contributions, making up approximately $17.64 \%(S D=25.26$; range $=0 \%$ to $100 \%)$. The lowest response was for the business sponsorships $(M=2.07 \%, S D=4.85$; range $=0 \%$ to $25 \%$. Other funding sources provided by the participants included donations, hosting a competition and group events, contributing approximately $3 \%(S D=11.68)$ of the budget, with a range of $0 \%$ to $60 \%$.

Items 24 and 25 of the survey asked the respondents about the student membership fees. Item 24 specially asked how much each student pays to be a part of the show choir. Responses to this item ranged from $\$ 0$ to $\$ 2,600$. These responses reported the average of the student membership fees were $\$ 459.35(S D=463.34)$. The median for this response was $\$ 380$. Seven participants responded that their students paid $\$ 0$ to be a member of the show choir. 
Item 25 was designed to determine whether there are opportunities provided for students to fundraise to help with their membership fees. The majority of the participants ( $n=42,60 \%$ ) responded that the students have the opportunity, but that it is optional. Very few $(n=7,10 \%)$ responded that there are no student membership fees required (see Table 11).

Table 11

Frequencies and Percentages of Opportunities to Participate in Fundraisers

\begin{tabular}{lcr}
\hline Statements & Frequency & $\%$ \\
\hline Yes, participation optional & 42 & 60 \\
No fundraisers to offset & 11 & 16 \\
individual fees & & \\
Yes, participation required & 10 & 14 \\
No student fees required & 7 & 10 \\
Total & 70 & 100 \\
\hline
\end{tabular}

Item 26 of the survey asked the respondents to indicate the approximate percentage of their budget that is spent on the following categories: music, choreography, costumes, props, travel, paid instrumental musicians and other. Costumes had the highest average expenditure $(M=31.56 \%, S D=16.92$; range $=0 \%$ to $70 \%$. With a range of $0 \%$ to $60 \%$, choreography expenses accounted for $21.98 \%(S D=12.84)$, which music was very close, with an average of $20.96 \%(S D=17.35$; range $=0 \%$ to $100 \%)$. With a range of $0 \%$ to $72 \%$, travel accounted for an average of $16.1 \%(S D=15.71)$. Props represented a relatively low percentage of the budget $(M=3.91 \%, S D=4.99$; range $=0 \%$ to $30 \%)$. Respondents provided some other examples of how they use their budget, as well. These expenditures included registration fees, equipment, retreats, clinicians and paying a band director. These responses averaged 3.3\% $(S D=13.54)$ of the budget, with a range of $0 \%$ 
to $100 \%$. Paid instrumental musicians were the lowest budget item $(\mathrm{M}=2.2 \%, \mathrm{SD}=$ 4.29 ; range $=0 \%$ to $16 \%$ ).

\section{Musical and Pedagogical}

Section six of the survey was designed to provide answers relevant to Research Question 2, with issues primarily relevant to choral pedagogy. In this section, respondents were asked about the size of the choir, vocal warm-ups, style of music, vocal technique and assessment.

Items 29 and 30 asked the respondents about characteristics of the choral department and the choirs. Item 29 specifically asked the respondents to indicate the size of the choral department (see Table 12). This item asked the participant for the total, not the sizes if individual ensembles.

Table 12

What is the total number of singers in the choral department?

\begin{tabular}{lcccccr}
\hline & Min & Max & Mdn & M & SD & Responses \\
\hline Total & 30 & 600 & 150 & 177.87 & 106.47 & 70 \\
Singers & & & & & & \\
\hline
\end{tabular}

Item 30 asked respondents to indicate how many singers in the varsity ensemble were represented in each specific voice part (see Table 13). The average size of the varsity ensemble was 45 members $(S D=12.59$; only 68 responses provided). The smallest varsity ensemble that was reported had 20 members, and the largest ensemble that was reported had 80 members. The median for the choir size was 46 . 
Table 13

How many singers of each voice part in the varsity show choir?

\begin{tabular}{lccccr}
\hline Voice Parts & Min & Max & M & SD & Responses \\
\hline Soprano & 5 & 20 & 12.72 & 3.69 & 68 \\
Alto & 5 & 20 & 12.35 & 3.69 & 68 \\
Tenor & 3 & 20 & 9.60 & 3.46 & 68 \\
Bass & 2 & 21 & 10.63 & 4.05 & 68 \\
\hline
\end{tabular}

Item 31 was designed to find out how many minutes the respondents were spending on each type of warm-up before the rehearsal. Participants responded to four categories: physical, mental, repertoire and other. Repertoire warm-ups accounted for the highest average minutes $(M=17.32, S D=28.51$; range $=0$ to 150$)$. Physical warm-ups were done for an average of 5.56 minutes $(S D=5.1$; range $=0$ to 30$)$, while mental warm-ups only averaged 2.81 minutes $(S D=3.58$; range $=0$ to 20$)$. Respondents reported on other examples of warm-ups that they do with their show choir, such as vocal warm-ups that are not repertoire warm-ups, and warm-ups focusing on balance, blend, tone and range. These were used for an average of 2.26 minutes $(S D=12.17$; range $=0$ to $100)$.

Item 32 asked the respondents to indicate an approximate percentage of each style of music that is learned or performed by the show choir from among the categories classical, pop, rock, Broadway, jazz and other. Pop music had the highest average response $(M=40.74 \%, S D=18.66$; range $=10 \%$ to $90 \%)$. With a range of $0 \%$ to $75 \%$, rock music averaged $21.45 \%(S D=15.37)$ with not all respondents responding $(n=69)$. Broadway music had an average of $19.06(S D=10.7$; range $=0 \%$ to $50 \%)$. Classical music accounted for about $14.01 \%$ of the literature $(S D=17.17 ; 0 \%$ to $60 \%$ ) with not all respondents responding $(n=69)$. Jazz music was not used very frequently $(M=4.51 \%$, 
$S D=7.27$; range $=0 \%$ to $30 \%$ ). Respondents provided other examples, including contest pieces, school songs and patriotic songs. These responses averaged only $0.73 \%(S D=$ 3.15 ; range $=0 \%$ to $20 \%)$.

Items 33 and 34 were designed to ask the respondents about vocal pedagogy. Item 33 asked the respondents to what extent each activity stated was practiced during a rehearsal (see Table 14). Pitch and intonation were used the most frequently by the participants at all rehearsals $(n=52,74 \%)$. Proper vocal singing was the next highest practice item used at all rehearsals $(n=51,73 \%)$. Most of the respondents reported that music reading was practiced during rehearsal, but there were a few $(n=4,6 \%)$ that responded that they never practiced music reading.

Table 14

Frequencies and Percentages of Items Practiced During Rehearsal

\begin{tabular}{|c|c|c|c|c|c|c|}
\hline Items & $\begin{array}{c}\text { All } \\
\text { Rehearsals }\end{array}$ & $\begin{array}{c}\text { Most } \\
\text { Rehearsals }\end{array}$ & $\begin{array}{c}\text { Many } \\
\text { Rehearsal } \\
\text { s }\end{array}$ & $\begin{array}{c}\text { Some } \\
\text { Rehearsals }\end{array}$ & Never & $N$ \\
\hline Pitch and intonation & $\begin{array}{c}52 \\
(74 \%)\end{array}$ & $\begin{array}{c}13 \\
(19 \%)\end{array}$ & $\begin{array}{c}4 \\
(6 \%)\end{array}$ & $\begin{array}{c}1 \\
(1 \%)\end{array}$ & $\begin{array}{c}0 \\
0 \\
(0 \%)\end{array}$ & 70 \\
\hline Proper vocal singing & $\begin{array}{c}51 \\
(73 \%)\end{array}$ & $\begin{array}{c}13 \\
(19 \%)\end{array}$ & $\begin{array}{c}4 \\
(6 \%)\end{array}$ & $\begin{array}{c}2 \\
(3 \%)\end{array}$ & $\begin{array}{c}0 \\
(0 \%)\end{array}$ & 70 \\
\hline Uniform vowels & $\begin{array}{c}50 \\
(71 \%)\end{array}$ & $\begin{array}{c}11 \\
(16 \%)\end{array}$ & $\begin{array}{c}7 \\
(10 \%)\end{array}$ & $\begin{array}{c}1 \\
(1 \%)\end{array}$ & $\begin{array}{c}0 \\
(0 \%)\end{array}$ & $69 *$ \\
\hline Vocal fundamentals & $\begin{array}{c}50 \\
(71 \%)\end{array}$ & $\begin{array}{c}11 \\
(16 \%)\end{array}$ & $\begin{array}{c}8 \\
(11 \%)\end{array}$ & $\begin{array}{c}1 \\
(1 \%)\end{array}$ & $\begin{array}{c}0 \\
(0 \%)\end{array}$ & 70 \\
\hline Diction & $\begin{array}{c}48 \\
(69 \%)\end{array}$ & $\begin{array}{c}17 \\
(24 \%)\end{array}$ & $\begin{array}{c}5 \\
(7 \%)\end{array}$ & $\begin{array}{c}0 \\
(0 \%)\end{array}$ & $\begin{array}{c}0 \\
(0 \%)\end{array}$ & 70 \\
\hline $\begin{array}{l}\text { Proper breath support } \\
\text { and breathing }\end{array}$ & $\begin{array}{c}44 \\
(63 \%)\end{array}$ & $\begin{array}{c}18 \\
(26 \%)\end{array}$ & $\begin{array}{c}4 \\
(6 \%)\end{array}$ & $\begin{array}{c}4 \\
(6 \%)\end{array}$ & $\begin{array}{c}0 \\
(0 \%)\end{array}$ & 70 \\
\hline Music reading & $\begin{array}{c}25 \\
(36 \%)\end{array}$ & $\begin{array}{c}20 \\
(29 \%)\end{array}$ & $\begin{array}{c}11 \\
(16 \%)\end{array}$ & $\begin{array}{c}10 \\
(14 \%)\end{array}$ & $\begin{array}{c}4 \\
(6 \%) \\
\end{array}$ & 70 \\
\hline
\end{tabular}

Note: The most frequent response to each statement appears in bold type. *One participant did not respond to this item

Item 34 used a 5-point Likert-type scale to determine the extent in which the respondents agreed or disagreed with the given statements, on a scale from: Strongly 
Agree to Strongly Disagree (see Table 15). A majority $(n=50,71 \%)$ Strongly agreed with the statement, "Beautiful choral tone is the end goal of the show choir(s)." A majority also Strongly agreed with the statement, "Different vocal technique is addressed depending on the song selection" $(n=40,57 \%)$.

Table 15

Frequencies and Percentages of Vocal Statements

\begin{tabular}{lcccccc}
\hline Statements & $\begin{array}{c}\text { Strongly } \\
\text { Agree }\end{array}$ & $\begin{array}{c}\text { Somewhat } \\
\text { Agree }\end{array}$ & $\begin{array}{c}\text { Neither } \\
\text { Agree } \\
\text { nor } \\
\text { Disagree }\end{array}$ & $\begin{array}{c}\text { Somewhat } \\
\text { Disagree }\end{array}$ & $\begin{array}{c}\text { Strongly } \\
\text { Disagree }\end{array}$ & $N$ \\
\hline $\begin{array}{c}\text { Beautiful choral tone is } \\
\text { the end goal of the }\end{array}$ & $\mathbf{5 0}$ & 17 & 0 & 3 & 0 & 70 \\
$\begin{array}{c}\text { show choir(s). } \\
\text { Different vocal technique } \\
\text { is address depending on } \\
\text { the song selection. }\end{array}$ & $\mathbf{4 0}$ & $(24 \%)$ & $(0 \%)$ & $(4 \%)$ & $(0 \%)$ & 0 \\
\hline
\end{tabular}

Note: The most frequent response to each statement appears in bold type.

Items 35 and 36 specially asked the respondents about vocal assessments that are done in the rehearsal. Item 35 asked how frequent vocal assessments are administered to check for proper vocal production. A majority of the respondents $(n=21,30 \%)$ responded that these assessments were given often. There were a few $(n=5,7 \%)$ that responded that these vocal assessments were never administered (see Table 16).

Table 16

Frequencies and Percentages of Vocal Assessments for Proper Vocal Production

\begin{tabular}{lcccccr}
\hline Responses & Frequently & Often & Sometimes & Infrequently & Never & Total \\
\hline Frequency & 16 & 21 & 17 & 11 & 5 & 70 \\
$\%$ & 23 & 30 & 24 & 16 & 7 & 100 \\
\hline
\end{tabular}

Item 36 asked the respondents how frequently vocal assessments are administered to check vocal parts (see Table 17). A majority of the respondents $(n=27,39 \%)$ 
responded that these assessments were given often. There were a few $(n=2,3 \%)$ that responded that these vocal assessments were never administered.

Table 17

Frequencies and Percentages of Vocal Assessments to Check Vocal Parts

\begin{tabular}{lcccccr}
\hline Responses & Frequently & Often & Sometimes & Infrequently & Never & Total \\
\hline Frequency & 17 & 27 & 15 & 9 & 2 & 70 \\
$\%$ & 24 & 39 & 21 & 13 & 3 & 100 \\
\hline
\end{tabular}

Item 37 was an open-ended question that allowed the participants to type in their response. The participants were asked, "Please describe any other content/goals/objectives covered in your show choir." There were 15 responses, but one of the responses was not relevant, so only 14 responses were analyzed. I assigned codes to the 14 responses to this open-ended question (see Appendix F for all responses). Based on the codes I categorized them into themes. The emergent themes for item 37 included: (a) dance/quality/stage presence $(n=12)$, (b) reflection $(n=1)$ and (c) teacher reflection $(n=1)$. Each theme will be discussed in the paragraphs that follow.

Dance/Quality/Stage Presence. This theme was present twelve times within the responses. Responses were coded into this category when they mentioned dance specifically or with other terms such as choreography or comments related to stage presence. One of the respondents stated, "How to look on stage singing and dancing. How to present yourself on stage." Another respondent stated, "Student behavior, how students present themselves daily, academic success (grades are closely monitored), choreography perfection, gratitude, family atmosphere, respect for teachers and parent volunteers." 
Student Reflection. There was one response that fit into this theme. Responses were coded into this category when they mentioned reflection specifically. A respondent stated, "Student reflection of a performance to plan future rehearsals."

Teacher Assessment. There was one response that fit into this theme. Responses were coded into this category when they mentioned assessment specifically. A respondent stated, "Because it is a function of my concert choir, we also need to meet state standards. I also assign and assess projects/tests in music history, music careers, music theory, and solo/small group performance."

\section{Benefits and Drawbacks}

The last section of the survey was designed to assist with answering Research Question 3, related to opinions about the show choir and its role in the choral department. Because the survey started with items related to the purpose of the show choir, I thought it would be appropriate to conclude with the benefits and drawbacks that the directors noticed.

Items 38 and 39 were designed to investigate the drawbacks of show choirs. Item 38 included a 5-point Likert-type scale with statements centered on potential drawbacks. Respondents indicated the extent of their agreement on a scale from: Strongly Agree to Strongly Disagree (see Table 18). With the first statement, "Show choirs are too time consuming," a majority of the respondents ( $n=21,30 \%)$ responded Somewhat Agree. However, not far behind 19 (28\%) responded Somewhat Disagree. In response to the second statement, "The price of the show choir results in students who are not able to participate," a majority of the participants $(n=22,32 \%)$ responded Somewhat Disagree. The next highest response to that issue was Somewhat Agree ( $n=15,22 \%)$. To the 
statement, "The choreography makes it difficult to keep the focus on proper singing," a majority of the participants $(n=21,31 \%)$ responded Somewhat Disagree. The next highest percentage (26\%) responded Somewhat Agree.

Table 18

Frequencies and Percentages of Responses to Potential Drawbacks

\begin{tabular}{lcccccc}
\hline Drawbacks & $\begin{array}{c}\text { Strongly } \\
\text { Agree }\end{array}$ & $\begin{array}{c}\text { Somewhat } \\
\text { Agree }\end{array}$ & $\begin{array}{c}\text { Neither } \\
\text { Agree nor } \\
\text { Disagree }\end{array}$ & $\begin{array}{c}\text { Somewhat } \\
\text { Disagree }\end{array}$ & $\begin{array}{c}\text { Strongly } \\
\text { Disagree }\end{array}$ & $N$ \\
\hline $\begin{array}{l}\text { Show choirs are too time } \\
\text { consuming. }\end{array}$ & 8 & $\mathbf{2 1}$ & 12 & 19 & 9 & 69 \\
$\begin{array}{c}\text { The price of show choir } \\
\text { results in students who }\end{array}$ & $(12 \%)$ & $\mathbf{( 3 0 \% )}$ & $(17 \%)$ & $(28 \%)$ & $(13 \%)$ & 69 \\
$\begin{array}{l}\text { are not able to } \\
\text { participate. }\end{array}$ & $(22 \%)$ & $(17 \%)$ & $\mathbf{2 2}$ & 12 & $(17 \%)$ \\
$\begin{array}{l}\text { The choreography makes } \\
\text { it difficult to keep the } \\
\text { focus on proper } \\
\text { singing. }\end{array}$ & 3 & 18 & 11 & $\mathbf{2 1}$ & 15 & 68 \\
\hline
\end{tabular}

Note: The most frequent response to each statement appears in bold type.

Item 39 was an open-ended question that allowed the respondents to type in their response. The respondents were asked, "Please describe any drawbacks you have experienced or can see with show choir." There were 36 responses to this open-ended question. I assigned codes to the 36 responses of this open-ended question (see Appendix $\mathrm{G}$ for all responses). Based on the codes, I categorized them into themes. The emergent themes for item 39 included: (a) draining/time commitment ( $n=11,30.56 \%)$, (b) more popular $(n=11,30.56 \%),(\mathrm{c})$ expense $(n=8,22.22 \%),(\mathrm{d})$ none $(n=4,11.11 \%)$, and (e) dance takes away $(n=2,5.56 \%)$. Each theme will be discussed in the paragraphs that follow.

Draining/Time Commitment. There were eleven respondents that had responses that fit into this theme. Responses were coded into this category when they mentioned draining/time commitment specifically, or with other terms such as energies or really 
busy. Most of the responses were more about how it was draining for the director rather than the student. One respondent stated:

While only $40 \%$ of my teaching load, it requires $80 \%$ or more of my “administrative” energies. Without consistent, conscious effort to build culture otherwise, show choir can become the "tail that wags the dog" in the choral program - parents and students believe that show choir is the most important component. It requires constant education and re-education into communicating that the concert choir and good musical foundations are the core of the choral program!

Another respondent stated, "As a teacher, just purely the time commitment it takes and managing all of the finances."

More Popular than Concert Choir. There were eleven responses that fit into this theme. Responses were coded into this category when they mentioned the term more popular specifically or with other terms such as detract. One of the respondents stated, "Pride and investment in show choir can/has detracted from pride/investment in Concert Choir class." Another respondent stated, "Students do not want to explore traditional choral music."

Expense. There were eight responses that fit into this theme. Responses were coded into this category when they mentioned expense specifically or when synonymous terms such as cost were used. One of the respondents stated:

Probably just the cost to the parent group. It is getting REALLY expensive to have a competitive show choir. Not sure the price compares with the outcome and what the kids are getting out of it anymore. I didn't used to feel this way, but it's 
getting really expensive. Some programs I know have had to eliminate that part of their programs.

Another respondent stated, "Expense. In order to be competitive, there is a certain level of investment in order to obtain quality custom arrangements, secure a choreographer that understands proper singing as it relates to choreography, and to purchase costumes."

None. Four respondents claimed that there were no drawbacks to show choir. Responses were coded into this category when they mentioned none specifically or when the response was positive. One respondent stated, "It's a great activity." Another respondent simply stated, "None."

Dance Takes Away from Singing. There were two responses that fit into this theme. Responses were coded into this category when they mentioned dance takes away specifically or less focus on vocal technique. One respondent stated, "Dancing can take away from vocal technique, choreography when executed correctly should not." Another respondent stated, "Does seem to focus less on vocal technique. All new to me."

Item 40 was an open-ended question that allowed the respondents to type in their response. The respondents were asked, "Please describe any benefits you have experienced or can see with show choir." There were 47 responses to this open-ended question, to which I assigned codes (see Appendix $\mathrm{H}$ for all responses). Based on the codes, I then categorized them into themes. The emergent themes for item 40 included: (a) life skills $(n=21,44.68 \%)$, (b) performing $(n=12,25.53 \%)$, (c) students' place ( $n=$ $9,19.15 \%)$, and (d) recruitment ( $n=5,10.64 \%)$. Each theme will be discussed in the paragraphs that follow. 
Life Skills. There were 21 responses that fit into this theme. Responses were coded into this category when they mentioned terms such as: discipline, leadership, teamwork and just being a human. One of the respondents stated, "The development of "soft-skills" is huge! Students may never sing/perform again after HS, but they will be teammates, workers, leaders, citizens \& people forever." Another respondent stated, "Students make lifelong friends and memories that will last a lifetime. They also learn other valuable skills to use for the rest of their lives (not just singing and dancing)."

Performing. There were twelve responses that fit into this theme. Many of the responses addressed how show choir helps students become better performers not just during school, but it sets them up to be a performer for life. One respondent stated:

We are able to introduce excellent standard literature for our singers for Christmas and once show choir season is ended. We continue to teach technique and sightreading to strengthen singers' grasp of vocal performance and adding emotional aspects to every performance.

Another respondent stated:

The students learn how to become well-rounded performers and build a stamina that will aid them in any performance opportunities they take in the future. They also learn punctuality, humility, teamwork on an immense level, and a myriad of other essential tools that will take them far in life.

Students' Place. There were nine responses that fit into this theme. This is a theme that was observed earlier when discussing "other purposes" of show choir. These responses were aimed to find out the effect of having a show choir as part of their program. One respondent stated, "Again, that students find 'their place' in the world." 
Another respondent stated, "Show choir has helped many of my students find a positive way of expressing themselves."

Recruitment. There were 5 responses that fit into this theme. Some of the respondents had seen an increase in the number of members in their whole program because of the show choir(s). One respondent stated, "We have recruited several students from our performances and by current members dragging friends in to try-out." Another respondent stated, "Huge recruitment tool. I can introduce traditional choral pieces to them and help them discover a love for that music and singing style."

Item 41 was an open-ended question that allowed the participants to type in their response. The participants were asked, "Please feel free to include any comments you may wish to make regarding the high school show choir." There were 17 responses to this item. I assigned codes to the 17 responses (see Appendix I for all responses). Based on the codes I categorized them into themes. The emergent themes for item 41 included: (a) positive ( $n=13,76.47 \%)$, (b) negative $(n=2,11.76 \%)$ and (c) rules $(n=2,11.76 \%)$.

Positive. Most of the responses gleamed a positive tone. This included being a well-rounded performer, finding "their place" and recruitment. One respondent stated: Show choir is a great outlet for students who need more movement in class, and I have witnessed it helping students who struggle in school and their personal lives. Traditional choir does this too, however, music is like every other art form and evolves over time and as artists, it is important to sing traditional repertoire, and know where all of our music came from, but there is still value in modern songs and musical skills to be learned through this repertoire and style of choir. 
Another respondent stated, "It is a great art form and activity to really push kids to be better than they thought they could be."

Negative. There were only two responses that fit this theme. One of the respondents felt that show choir was on the "downward slide." This respondent stated: Participation levels are dropping, associated websites see far less traffic than 10 years ago, sponsored competitions are seeing attendance numbers drop, fundraisers produce fewer dollars. There are too many other things now to claim a student's time and devotion (after school jobs, for one).

Another respondent had mixed feelings. This respondent is at the end of their teaching career. This respondent stated, "I think it is a young person/director sport."

Rules. There were two responses that fit into this theme. These two respondents were concerned that there are no rubrics for show choirs and there is not a consistent governing body over the judges' training. One of the respondents stated, "I wish we had a standardized rubric for show choirs." The other respondent stated, "I wish there was a consistent governing body over judges training (similar to marching band/winter guard competitions). In our short time of competing, we've seen very different results at each competition, sometimes completely mystifying to myself and my kids."

\section{Further Investigation}

There are several aspects of the data that may be interrelated. Thus, I investigated possible relationships between school size and choral department size, as well as choral department size and ensemble size. I also sought to determine whether there were correlations between budget and school size, choral department size and choir size. 
Pearson Product-Moment correlations were used for all calculations, with the alpha level set at .05 for all calculations.

The first correlation computed was for school size and choral department size for 69 respondents who provided both responses. The result indicated that there was a significant positive relationship between school size and choral department size r (67) = $0.61, \mathrm{p}<.05$

The correlation of choral department size with the size of the varsity show choir was computed for the 68 respondents providing data for both items. The result indicated a significant positive relationship between choral department size and the size of the varsity show choir, $r(66)=0.25, \mathrm{p}<.05$.

The relationship between the budget and the school size was computed for the 60 useable responses. The results indicate the relationship between the budget and the school size was not significant, $r(58)=0.23, \mathrm{p}>.05$. The budget of the show choir also was not significant with choral department size, $r(58)=0.21, \mathrm{p}>.05$.

I also investigated the relationship between the budget of the show choir with the size of the ensemble for all responses that included complete information in both categories $(n=58)$. The results indicated a significant positive relationship between the budget and the size of the ensemble, $r(56)=0.37, \mathrm{p}<.05$.

\section{Summary}

Results of this analysis indicated that the majority of the director participants were male $(65 \%)$ and had been teaching for an average of 16.26 years. Most of the respondents were from the North Central (31\%) and Southwestern (33\%) divisions of American 
Choral Directors Association. The majority taught in an established program (84\%), and $41 \%$ taught two show choirs.

A majority of the respondents strongly agreed that some of the main purposes of the show choir were to provide students a chance to perform a variety of musical styles, serve as a recruitment tool and allow students to have a well-rounded choral experience. Most of the show choirs are open to students in grades $9-12$ and are separate from the concert choir. Many of the show choirs use custom arrangements and hire a professional choreographer. Most use a live band including students, perhaps with 1 or 2 adults. Most of the competitions that choirs attend are high school sponsored competitions.

Most of the show choirs rely on student membership fees to help with the cost of the show choir. The average for a student to pay is $\$ 459.35$ per year with the median being $\$ 380$, but many of the directors responded that the students have opportunities to fundraise for those fees. Most of the budget is spent on music, choreography and costumes.

When warming up, an average of 5.56 minutes is spent on physical, and 2.86 minutes on mental warm-ups. Most of the time, 17.32 minutes, is spent on repertoire warm-ups. The data indicate that $40.74 \%$ of the music repertoire used is pop music. Most of the directors responded that music reading, vocal fundamentals, proper vocal singing, uniform vowels, diction, pitch and intonation and proper breath support and breathing are practiced in all rehearsals. The directors also strongly agreed that different vocal techniques are addressed, depending on the song selection, and that beautiful choral tone is the end goal of the show choir. Vocal assessments are often given to the students to check proper vocal production and vocal parts. 
Participants did not report many drawbacks to having a show choir, although the directors somewhat agreed that show choirs are too time consuming. However, the directors somewhat disagreed that the price can keep students from participating, or that the choreography makes it hard to keep the focus on proper singing.

Overall, the responses indicated that show choir can be a positive experience for students and directors. Eighty-three percent of the directors felt that show choir provides the students a chance to perform a variety of musical styles and incorporate multiple disciplines like dance, band and theatre. Not only are the directors involving singers, but also student band members (52.24\%). The written responses of the participants indicated that show choir allows the students a "safe place" and a place they can call home. 


\section{CHAPTER FIVE}

\section{Discussion}

In designing this study, I sought to provide educators and researchers with information to help them understand the role and characteristics of the varsity show choir in a high school choral department. With these data, teachers, administrators and school districts can compare their own programs against a national sample of responses. Teachers seeking to start a show choir, or new teachers evaluating job opportunities, should also find this information to be useful in their decision-making process.

Varsity show choir directors from the United States were invited to participate in a survey through the Facebook page, "Show Choir Connect" and through email, for those directors that were not members of the Facebook group. This survey was used to collect information regarding demographics, logistics, auditions, budget, musical and pedagogical information, the purpose and role of the show choir, and directors' opinions regarding benefits and drawbacks to having a show choir.

\section{Demographics}

The respondents of this study were predominately male with an average of 16 years of teaching experience. I did not ask the respondents what level of a college degree they had, but future researchers may wish to inquire about this to see if these teachers have earned a degree beyond a bachelor's degree. I asked the respondents how many students attended their school and there was a wide range, from 180 to 9,000. Future researchers may want to investigate this by type of community, such as rural and urban, to see how this may affect the shows choir offerings. Another question that future researchers would want to ask is whether the schools are public or private, as this could 
lead to other implications, such as budget comparisons between tuition-based private schools and public schools.

Most of the respondents represented the North Central (Iowa, Minnesota, Nebraska, North Dakota, South Dakota and Wisconsin) and the Southwestern (Arkansas, Colorado, Kansas, Missouri, New Mexico, Oklahoma and Texas) divisions of the American Choral Directors Association. It is interesting that the Eastern, Northwestern, Southern and Western were not represented as well. This raises the question of whether show choir is not popular in those regions, if those directors are not part of the Facebook page, or if they chose not to respond. Future researchers might wish to reach out to directors from those divisions to determine the whether there actually are regional differences related to the popularity and availability of show choirs.

Most of the show choir programs were already established when the director came into that position. It would be of interest to find out how long the show choirs had been in operation. There is evidence in the historical literature of the first show choir beginning in 1963 but there is not information about patterns of growth over time. Inquiring of directors how long the show choirs have been offered at their schools may be helpful in an initial attempt to create a timeline of show choir offerings.

\section{Logistics, scheduling, time, and budget}

Research Question 1 asked, "What characterizes the high school show choir with respect to logistics, including scheduling, time, and budget?" Answers to these questions was intended to provide baseline data about show choirs from this national sample of respondents. 
Regarding the scheduling and time it takes to have a show choir, the majority of the directors reported having rehearsals outside of the school day often or frequently, with $28 \%$ of the groups meeting outside of the regular school day only. The data revealed that $42 \%$ of the respondents agreed with the statement, "show choirs are too time consuming," while $41 \%$ disagreed with this statement. It was interesting to see that these directors were almost equally divided in their responses to this statement. It would be enlightening to find out more about the directors and why they responded the way that they did. Do they have a family? Are they almost ready to retire? It would be interesting to see if there is a relationship between aspects or stages of a director's personal life and responses to this question, to help provide teachers with realistic expectations about issues related to time commitments.

Specific questions about the budget were asked of the respondents. The data revealed some surprising numbers as to the amount of money spent. These directors were working with a very wide range of budgets, from $\$ 0$ to $\$ 300,000$, with a median expenditure of about $\$ 30,000$ per year. Most of the respondents reported that students had to pay a membership fee, but also that students had the chance to fundraise to help offset those fees. This aligns with previous research and literature about required "pay to play" fees (Cassidy 2013; Dollins, 2011; Mack, 2011). There is some concern with how expensive show choirs are becoming. The data indicated that student membership fees contributed the largest percentage of the budget, with parent booster organizations, school/district, student fundraisers, business sponsorships and other entities following, in that order. This raises questions related to the socioeconomics of the area and of the students and their families. The extent to which show choir budgets relate to type of 
school (public or private) or characteristics of the school and community could not be addressed by the data gathered.

Some of the major budget items for show choirs are for music and choreography. The data revealed that most of the show choirs were using custom arrangements, which means paying the fees for the copyrights and the arrangers. The predominance of custom arrangements corresponds with the findings by Alder and Mulvihill (2016). Not only are participants using custom arrangements, but $68 \%$ of the participants reported hiring a professional choreographer. Music and choreography expenses comprised almost equal proportions of the budget, accounting for a total of about $43 \%$ of the choirs' expenditures.

Although the music and the choreography are integral components of a show choir, these directors reported that costumes were the single largest expenditure, averaging over $31 \%$ of their budget. Travel played a part in the budget for some of the respondents, as well. Future researchers may want to ask specifically how much directors are spending on music, choreography, costumes and other items, because in this research the respondents were asked to give a percentage. Obtaining actual budget information from various programs would provide a more in-depth picture of show choir funding and how it is being used, so that researchers and educators would be able to see the actual costs of what directors and school districts are spending on each area.

Another factor that plays into the budget is the price for competitions. There is a wide range of prices for competitions across the nation. It would be interesting to see what directors are spending to attend a competition, and if price enters into their decisions about which or how many events to attend. Most of respondents reported attending high school sponsored events. It has been my experience that high schools that 
are hosting competitions are using entry fees as a fundraiser to help with their show choir budget. Future research might want to look into those schools that host competitions and see what they are charging and how much the schools earn by hosting a competition, to help figure additional budgeting details.

\section{Musical/pedagogical, student selection, and rehearsal/performance}

\section{practices/activities}

Research Question 2 asked, "What characterizes the musical and pedagogical aspects of the high school show choir, including student selection and participation, rehearsal and performance practices, performance activities, choral/vocal pedagogy?" The role of the show choir within the school's choral program was an important item of interest here. The data revealed that most of the show choirs were separate from the concert choir. Fifty-four percent of the respondents indicated that if the students wanted to be in show choir, they must also participate in the concert choir. It is a bit concerning, however, that only half of the schools required that the show choir students participate in concert choirs, and that for over a fourth, show choir served as the concert choir for the entire year. This raises the question — are the students participating in show choirs that are also serving as the concert choirs are actually learning traditional choral music?

According to the data reported, the directors were still working on vocal pedagogy in their show choir rehearsals, but how much of their year was actually spent on non-show choir music? Are these students truly getting a well-rounded choral experience? According to the premise of the National Show Choir standards the show choir should not be a replacement for a traditional choral program (https://archives.acda.org/page.asp?page=showchoirstandards). 
All of these directors were holding auditions to select their varsity show choir, with $100 \%$ of the respondents requiring the students sing at their audition. An interesting aspect is that most, but not all, of the respondents require their students dance as part of their audition. It would be informative for show choir directors for future research to find out more about how the audition process is being handled. Are the directors choosing the song that the students have to sing, or are the students getting to choose their own song. Are the songs accompanied or do they allow the students to sing a cappella? Why do some of the directors not require a dance portion of the audition? Learning more about aspects of high school show choir auditions may help college directors understand the prior experiences of students auditioning for their ensembles, as well.

When asked who comprised the show choir band, most of the respondents reported using student musicians, with perhaps an additional adult or two. This provides the opportunity for students to play a part in the show choir who may not otherwise have the chance be a part of this ensemble, and may provide a place for some students who want to perform this style of music who do not have that option in the other school instrumental ensembles. Current practices align with standard 3, Instrumental Accompaniment, provided by ACDA (https://archives.acda.org/page.asp?page=showchoirstandards). One challenge is that it the instrumentalists may not be available for rehearsals with the choir during the day, a problem exacerbated by the report that there are adults included in the bands. This necessitates extra rehearsals before or after school so that the band can rehearse with the choir, contributing to the time drawbacks of these choirs. I suggest that the drummer be in every rehearsal, if it is possible, based on my experience. I had my drummer enroll in 
show choir just like the other members, so the drummer was able to really get a feel for the show, where to put cymbal crashes, and so forth. I believe this also resulted in the drummer feeling like part of the show choir family.

Most of the directors reported using pop, rock and Broadway music. Classical was used by some, but I wonder if that was for their actual show choir show, or if that is also literature used when the show choir doubles as the concert choir, or repertoire used for other types of festivals or contests. The variety of music used aligns with the literature stating that it is the director's job to provide the students with more than one musical approach and to present them with a plethora of musical styles (Mack, 2011). This also aligns with standard 1, Singing, provided by ACDA (https://archives.acda.org/page.asp?page=showchoirstandards). This again raises the question about how the directors are getting their music. Because most are from custom arrangements, it would be interesting to dig deeper and find out how they are arranged, by whom, and to investigate to see if these would be considered high quality, as described by Fredrickson (2004). Asking more in-depth question about the actual genres of music, and obtaining copies of programs, or even the music, for analysis could provide a more complete picture of show choir repertoire. It would also be interesting to consider how directors plan a show (Mack, 2011) —whether they start with theme or just put selected songs together.

The data revealed that most show choirs are practicing music reading, vocal fundamentals, proper vocal singing, uniform vowels, diction, pitch and intonation and proper breath support. This is consistent with the previous literature about learning how to create that vibrant choral tone (Lanier, 2007), and with standard 1, Singing, that ACDA 
provides (https://archives.acda.org/page.asp?page=showchoirstandards). This corresponds with much of the literature about making sure to keep the singers well rounded. Respondents reported that different vocal styles were addressed depending on the song, and that beautiful vocal tone was the end goal of the show choir. Future researchers may want to delve further into this information and ask how much time is spent on each style. Observing show choir rehearsals could be an enlightening way to obtain information about the vocal techniques being taught.

The data revealed that proper assessments are being used by most of these directors. This works well with implementation of standard 5, Interpreting Music Elements, standard 6, Stylistic Awareness and standard 7, Performance Practices and Evaluation which are provided by ACDA (https://archives.acda.org/page.asp?page=showchoirstandards). However, there were a few show choir directors not using any type of assessment with the choir. Perhaps those responses were for the choirs that are strictly extracurricular. I would suggest that all directors take the time to assess the students in their ensembles. Assessing will provide insights to use in rehearsal planning for student growth. Future researchers may want to look at the type of assessments that are being given and how they align with the ACDA standards. It would also be interesting to see why some are not giving assessments to check for vocal technique and/or parts. Maybe those directors are assessing in an informal manner or using other types of assessments that tie everything together more comprehensively.

Questionnaire items were included to inquire about specific elements of pedagogy. In response to items about their warm-up practices, participants revealed that 
they spent the most time on repertoire warm-ups. It was interesting to see that they did not spend much time on physical or mental warm-ups. It seems that some of these directors are not following through with all three of the main warm-ups, according to recommendations in the literature (Webb, 2007). Based on my experiences, I would suggest that directors take the time to make sure that they are fully warming up their choir not just vocally, but physically and mentally. This will lead not only to a betterfocused rehearsal, but also more focus when it is competition time. We tell our students to rehearse how they would perform, so we as directors need to make sure that we do not skip steps along the way. For future research it would be interesting to see what the warm-ups entail, if the warm-ups that the directors are doing align with the literature, and whether they are using the same warm-ups as in their traditional choir (Pomfret, 2012). Researchers might want to ask the directors about specific warm-ups and figure out why they are spending so much time on repertoire warm-ups and not as much time on physical and mental warm-ups. Again, observational studies could provide some of these answers.

\section{Purpose, benefits and drawbacks}

Research Question 3 asked, “According to high school choral directors, what are the purposes, benefits and drawbacks of having show choir(s) in the choral department?" Whereas the first two research questions were designed to address more concrete aspects of show choirs, the intent here was to obtain the opinions and attitudes of directors representing different areas and communities in this national sample.

Potential purposes of show choirs were presented as a questionnaire item, to which the participants responded on a scale from strongly agree to strongly disagree. The findings aligned with the previous literature, in that there were differing ideas about the 
show choir's role in the curriculum (Shaw \& Thomas, 2005). Data revealed that $99 \%$ of the directors agreed with the statement, "A main purpose/role of the show choir is to provide the students a chance to perform a variety of musical styles and incorporate multiple disciplines like dance, band and theatre." This relates with another statement, "Show choir allows students to have a well-rounded choral experience," with which 91\% of the respondents agreed. These statements align with the purpose and premise of the National Show Choir Standards that are provided by ACDA (https://archives.acda.org/page.asp?page=showchoirstandards).

The data revealed that $84 \%$ of participants agreed with the statement, "The show choir is the main recruitment tool for the choral department." This is consistent with some of the previous literature, which advised that having a show choir in a school's choral department can enhance the school's activities program (Dollins, 2011). However, in a study that investigated the male enrollment of choral programs, it was found that programs that had a show choir had the same average male enrollment as those programs that did not have a show choir (Johnson, 2007; Johnson, 2004), so at least in this aspect, the results are inconclusive. The current data indicated that there were 2 to 3 fewer males than females in the choirs, but I did not ask about the proportion of students who auditioned and were not selected. Determining gender-related aspects of participation show and concert choirs could be an interesting item for future research.

When the respondents had the chance to write in their own thoughts about the purpose of a show choir, they responded that it provides opportunity for teamwork, challenges students, develops life skills outside of the classroom, provides a safe place and builds confidence. Future researchers may want to explore these topics even further, 
for example, examining the aspects of teamwork and how that plays a role in the purpose of the show choir. The responses provided are consistent with ACDA standard 9, Entertainment as Art and standard 10, History and Pop Culture (https://archives.acda.org/page.asp?page=showchoirstandards).

In an effort to develop a more complete and balanced view of the show choir from the directors' perspective, respondents were asked to rate some possible drawbacks provided in list form, and then were given the opportunity to respond with their own written responses. As reported earlier, data revealed that these directors were divided in their opinions about whether the show choir was "too time consuming." Also found was that $53 \%$ were not concerned about the choreography taking away from the vocals. The data revealed that $49 \%$ of the directors did not find the price of show choir to be a drawback. This brings up the question again of whether these are public or private schools? Are these schools rural, suburban or urban? What is the socioeconomic background of these students that make the directors feel that it is not too expensive?

Based on the open-ended responses, the most frequent concerns expressed were about time commitment. One of the respondents stated that show choir was "a young directors sport." This is why future researchers might want to find out the ages and/or family characteristics of the directors, to see if those played a part considering that it was too time consuming an endeavor. Interesting enough, most of the answers were not about the students being constricted with time, but dealt with the director being constricted with time, and putting more hours into that group than their other choirs. This makes me wonder if this comes down to the director's attitude toward show choir as a genre as to whether it is considered too time consuming. For those directors that feel this way, is it 
just the extra rehearsals or is it the competitions on the weekends that they are considering? I wonder if the directors have help from parents or other staff, or whether they are trying to do everything on their own? I would recommend that if the director is trying to do everything by themselves it is time to start delegating and to see where they could possibly gain assistance from others. I was fortunate to have a helpful accompanist who stepped in to take responsibility for some aspects for me. I also had a wonderful booster organization that was always willing to assist. Directors also expressed concerns about the show choir being more popular than the concert choir. Future researchers may want to explore more about the directors who do or do not require the students to be a part of the concert choir. Could that be responsible for these concerns? Should students be required to participate in concert choir if they want to be in the show choir, even if the show choir is promoting a well-rounded choral experience?

Data seemed to indicate that the participants believed that the benefits outweighed the drawbacks. This is consistent with the opinion that having the students experience a wide range of interests actually enhances their whole educational experience (Shaw \& Thomas, 2005). It seemed that most of the directors were supportive of having a show choir because of the benefits that it provides the students. The most popular benefit was about teaching the students life skills. Respondents indicated that show choir taught the students more than just music — that being a part of a show choir taught the students how to be successful humans in today's world. Of course, studies focusing on the experiences and attitudes of students enrolled in show choirs could provide enlightening information regarding many aspects of these data. 


\section{Correlation of school, department, choir size and budget}

After reviewing the data from the survey, I was curious whether there might be some correlations between certain demographic items. This resulted in Research Question 4, Are there any relationships between school size, choral department size, ensemble size and budget? The results indicated that there was a strong positive relationship between school size and the choral department size. Although this is not surprising, it would be interesting to dive deeper and get a better understanding about the different schools and the types of communities in which they were located, such as suggested previously. This could then be related to recruitment, to see if the students are participating because they attend a small school where students are involved in multiple activities, or if the students are choosing show choir over other activities.

Data revealed that there was also a strong significant relationship between the show choir budget and the size of the ensemble. What would be interesting to find out is if there was a possibility that the small ensembles were being disadvantaged, because arranger, copyright, and choreographer fees would not differ much, if at all, according to group size. The extent to which the budget determined the potential size of the group, or the size of the group determined the budget by providing more membership fees, is unclear. Students' financial responsibility for participation should be an item of concern if music educators want all students to be able to access all school ensembles equitably. Perhaps students at private schools who already pay high tuition are not charged a fee or required to work on fundraisers to participate in show choir. Future researchers may want to explore more about the student's demographics, especially with what percentage of the 
students are on free and reduced lunch, with respect to the financial obligations of participation.

There was a significant relationship between choral department size and the size of the varsity show choir. It would be interesting to research this further by seeing if this is because of using show choir as a recruitment tool, or if this is a result of students being required to participate in the concert choir.

It was very interesting and surprising was that the relationships between the budget and school size, and the budget of the show choir with the choral department size, were not significant. This brings up another question; if the directors have multiple show choirs, were they dividing their budget among them, or did each show choir receive the same amount of money? Further research could be done into this information to see why there is no correlation between these items.

\section{Implications}

The results of this study provide educators with information upon which to gain a better understanding of a variety of aspects of the high school varsity show choir, including directors' responses regarding the ensemble's role and educational purposes as part of a choral program. These data also provide educators and administrators with an idea of what may be required to offer a show choir program with respect to finances, time commitments, and other logistical aspects.

The role. Findings from this study indicated that the directors felt that the role of the show choir was to make sure that the students were receiving a well-rounded choral experience, by having their students exposed to different genres across the musical 
spectrum. The show choir was also allowing for the integration of multiple disciplines including dance, band and theatre.

Logistics. Offering a show choir is going to require time and money. However, the size of the budget and extent of the choir's activities is up to the director, students, parents and school district, as these data indicated that there were wide ranges in budget size and level of participation in competitions. Show choirs do not need to spend lots of money, especially if they choose not to compete. However, if the director does wish to compete, everyone involved must understand that it is going to take both money and time. A competitive show choir will take up more than just the normal classroom time, including many nights and/or early mornings and weekends with their students. The show choir is going to need money for costumes, music, choreography and other items such as props and entry fees. The director, parents, boosters and school district are going to have to take the time to fundraise and be willing to help students who may not be able to afford to pay the membership or travel fees.

Musical and pedagogical aspects. It seems important to remember that the show choir is a choral ensemble first and foremost. It has been my experience that the director has to work with the choreographer to have the moves match the vocals. This study showed that directors are focused on having proper vocal technique, and that these students are learning about the basics of singing while being exposed to a variety of different musical styles. Thus, the students are learning proper vocal techniques for the different styles, which is especially true given that most of the students need to be enrolled in the traditional choir. This will allow for the teachings to transfer, and types of choirs should benefit as a result. 
Benefits and drawbacks. The biggest drawback mentioned was the time commitment. If director wishes to have a successful show choir, the must plan to devote time to this choir that they likely would not normally have to devote to a traditional choir. This is not just the time that it is going to take with the students, but also with the time spent working with other aspects and individuals, such as choreographer and arranger. The director is going to have to devote time to plan out fundraisers, perhaps in conjunction with booster groups, to help those students offset the costs.

This study also showed that a potential drawback was that the show choir was becoming more popular than the traditional choir. I believe that this can only happen if the director allows it to happen. If the show choir becomes the director's priority, then it is going to take over the program. The director should ensure that the traditional choir is viewed to be as important as the show choir and remind their parents and students that the show choir is a just one branch of the choral department. I suggest that future researchers investigate how show choir can enhance the traditional choir, possibly through building enthusiasm and community in the choral program and/or school.

Having a show choir can benefit the choral department. As the data indicated, it provides another opportunity for the students to learn more than just music, including learning life skills that they can use not only while in school and in choir, but also once they graduate. Students are learning how to be a part of a team, and they are also learning how to be performers. This transfers over not only to singing, but how to present themselves in front of an audience. Lastly, the show choir provides a safe place for the students. For some it is described as being more than just a class; it is a family. 


\section{Limitations}

There were several limitations of this study that will provide guidance for future research. The data that were reported for these 70 programs can't be generalized to all show choirs, although they provide information from a national survey that may be of interest to directors and help start conversations about the various aspects reported. The way that the respondents were recruited limited the population surveyed. This survey was

only open to show choir directors, so responses were not received from directors who did not teach a show choir. Future research may want to include those directors to learn their thought processes and reasoning about why they or their school has chosen not to offer this ensemble. Additional data that future researchers may want to gather would be to survey stakeholders who are not choir directors to learn about their perspectives. This could include, but not be limited to, dance instructors, vocal coaches, arrangers, choreographers and parents.

Another limitation was not being able to determine the exact response rate. Social media was used to recruit directors of show choirs, as was email if a director was not part of the social media page. There is no way of being able to know the exact number of directors that saw the post, met the qualifications for this study and actually clicked on the online survey link.

\section{Additional Suggestions for Research}

Research in this area is limited, and future studies should seek to understand further the many different aspects of the show choir that this study began to address. The literature reviewed for this study indicated that many directors do not know how to go about teaching a show choir or do not feel that they have enough information to run a 
successful show choir (Alder \& Mulvihill, 2016; Thomas, 2006). In what may be a parallel result, the author of a previous study about concert, marching and jazz band reported that directors had less undergraduate and professional pedagogical experiences with jazz ensembles than with the other, perhaps more prevalent, ensembles (Regier, 2018). Future researchers may want to explore the education that future choral directors are receiving from colleges and universities. Are their courses focused on teaching traditional choirs, and other educational aspects like how to run classroom, lesson planning and rehearsing, and are they receiving sufficient information in their music education method courses about teaching show choirs specifically? In my college studies, I was required to take an elementary methods course, junior high methods course and a secondary methods course, but we did not address show choir in those classes. Luckily, I had experiences to draw on when I began to teach, because I had participated in show choir in high school and in college. I would suggest that colleges and universities incorporate show choir pedagogy into their methods courses, if they are not already, so that the new teachers feel well equipped to handle teaching this type of ensemble. The findings of this study could be used as baseline information in order to give students information on what to expect and directors' attitudes regarding working with show choirs.

Future researchers may want to compare aspects of the show choir with the traditional choir, including musical and pedagogical aspects such as breathing, vocal tone and technique. Future studies should examine the musical arrangements and choreography in depth to gain an understanding of the music and movement characteristics and the skills required of the students. The competitions that the show 
choirs are attending or not attending, and how directors make these decisions, would be interesting to study, including characteristics of the show choir competitions that are offered at the state level by several states.

The results of this study lead to new questions about competitions and budget. Exactly how much are schools spending on specific fees charged by arrangers, choreographers, competitions, and for copyright fees? Are the expenses, student fees and fundraising preventing some schools from offering show choir and/or some students from participating?

Examining different show choirs using other quantitative and qualitative methods (such as interviews and video recordings) would help to provide more perspectives on this topic, including those of the students who participate. A replication of this study could zoom in geographically instead of surveying directors across the whole United States and just survey an individual division of ACDA, or perhaps look more in depth at schools from the different regions within the ACDA divisions to compare how states/regions may differ. Future researchers may want to explore the areas from which there were not many responses to see if students in all regions have similar access to show choir participation.

\section{Concluding Statement}

This investigation provides baseline data and insights into the role of the show choir in the high school choral department. The key findings were that the show choirs' main purpose was perceived to be to provide the students a chance to perform a variety of musical styles and incorporate multiple disciplines such as dance, band and theatre, which in return helps to give the students a well-rounded choral experience. In order to 
have a successful competitive show choir, teachers and district administrators need to know that it is going to require time and fiscal resources, although non-competitive choirs could be less expensive to offer.

The directors surveyed indicated that show choir provides a safe place for students to be in the school, and a place to gain important skills to use not just in the choir room, but also in life. Having a show choir in the choral department can provide a satisfying experience for students and enhance the school's vocal music program (Lanier, 2007). The findings of this study provide educational reasons in support of the role the show choir plays in the choral curriculum, which also may help justify the commitment of time and expense. I hope that the information provided will encourage directors to take a chance with show choir if they do not already have one, as the respondents overwhelmingly found this to be a positive endeavor. If the directors already have a show choir, these research data can provide a baseline against which teachers, administrators and school districts can compare their own programs with a national sample of responses. 


\section{References}

Alder, A. L. (2012). Successful high school show choir directors: Their perceptions about their teaching and administrative practices. DA, Ball State University. ProQuest Dissertations \& Theses: Social Sciences, ProQuest Dissertations \& Theses: The Arts.

Alder, A. L., \& Muhlvihill, T. M. (2016). The show choir handbook. Lanham, MD: Rowman \& Littlefield.

American Choral Directors Association. (2018). American choral directors association chapters. Retrieved from https://acda.org/ACDA/About/Chapters/ACDA/AboutRoot/Chapters.aspx?hkey=26586778-fd6b-4024-af7f-87f4c07f1b62

American Choral Directors Association. (2018). Repertoire show choir r\&s standards. Retrieved from https://archives.acda.org/page.asp?page=showchoirstandards

American Psychological Association. (2010). Publication manual of the American Psychological Association (6th ed.). Washington, DC: American Psychological Association.

Cassidy, T. J. (2013). Modern a cappella-pop and show choir methods for the classically trained music educator (Master's thesis). Retrieved from http://hdl.handle.net/2097/15629

Creswell, J. W. (2007). Qualitative inquiry \& research design: Choosing among five approaches (2nd ed.). Thousand Oaks, CA: Sage.

Dollins, K. (2011). Beauty and the beast: The nature of a show choir. The Choral Journal, 51(10), 53-56.

Fink, A. (2009). How to conduct surveys: A step-by-step guide ( $4^{\text {th }}$ ed.). Thousand Oaks, CA: Sage.

Fredrickson, S. (2004). Popular choral handbook: New techniques for pop, jazz, and show choir directors. ScottMusic.com.

Glover, S. L. (2001). How and why vocal solo and choral warm-ups differ. The Choral Journal, 42(3), 17-22.

Hylton, J. (1987). Keeping your choir on the move. Music Educators Journal, 74(3), 3134. Retrieved from http://www.jstor.org.proxy.mul.missouri.edu/stable/3397938 
Jennings, B. L. (2017). The elements and methods of a successful show choir (Order No. 10608452). Available from ProQuest Dissertations \& Theses A\&I. (1957414918). Retrieved from http://proxy.mul.missouri.edu/login?url=https://search-proquestcom.proxy.mul.missouri.edu/docview/1957414918?accountid=14576

Johnson, D. L. (2004). The impact of competitive show choir on the enrollment of male singers in choral ensembles in nebraska and iowa (Order No. EP74424). Available from ProQuest Dissertations \& Theses A\&I. (1705577824). Retrieved from http://proxy.mul.missouri.edu/login?url=https://search-proquestcom.proxy.mul.missouri.edu/docview/1705577824?accountid=14576

Johnson, D. (2007). Show Choirs: Show choir competition and the impact on male recruitment. The Choral Journal, 47(10), 50-53.

Lanier, B. (2007). Show choirs: Keeping the choir in show choir. The Choral Journal, 48(2), 35-37.

Mack, V. L. (2011). Putting the show in choir: The ultimate handbook for your rehearsal. Milwaukee, WI: Shawnee Press.

National Center for Education Statistics (2019). Retrieved from https://nces.ed.gov/forum/index.asp

Pomfret, B. (2012). Vocalizing vocalises. Journal of Singing, 69(1), 61-66.

Qualtrics Labs, Inc. (2018). http://www.qualtrics.com. Provo, UT: Qualtrics Labs, Inc.

Regier, B. J. (2018). A measurement of self-efficacy among oklahoma secondary band directors in concert, marching, and jazz ensemble pedagogy. Update: Applications of Research in Music Education. Advance online publication. doi: $10.1177 / 8755123318808246$

School Courses for the Exchange of Data (2019). Version 6.0. Retrieved from https://nces.ed.gov/forum/sced_resources.asp

Shaw, K., \& Thomas, K. (2005). Show Choirs: Competitive show choir festivals: What are the benefits?. The Choral Journal, 45(7), 107-109.

Spradling, D. R. (2001). National standards of excellence. The Choral Journal, 42(5), 6162.

Spurgeon, D. (2004). Vocal pedagogy skills for the undergraduate choral conductor. Journal of Music Teacher Education, 13(2), 28-33.

Thomas, K. (2006). Show choirs: Another choir? How about a show choir?. The Choral Journal, 46(8), 45-46. 
Weaver, M. \& Hart, C. (2011). Sweat, tears, and jazz hands: The official history of show choir from vaudeville to glee. Milwaukee, WI: Hal Leonard Books.

Webb, J. L. (2007). Promoting vocal health in the choral rehearsal. Music Educators Journal, 93(5), 26-31. 


\section{The Role of the Show Choir in the High School Choral Department}

\section{Start of Block: Block 8}

Thank you for choosing to participate in this research project, entitled "The Role of the Show Choir in the High School Choral Department." Please only complete this survey if you are a high school choral director that has a mixed varsity show choir. The purpose of this study is to contribute to the understanding of what role the show choir plays in the high school choral department. This will include the logistics of show choir programs, the musical and pedagogical aspects, and the benefits and drawbacks to having a show choir program. Findings of this study may be published and presented at professional conferences.

The survey that follows should take approximately 12 minutes to complete. It is unlikely you will experience any risks from participation in this study. Your participation in this research is completely voluntary. Although I hope you will complete the whole survey, you are free to decline to answer any items, as you choose. You may remove yourself from the research study at any point without penalty.

Your responses to the survey items will be completely anonymous, and there will be no way for me to connect survey responses with respondents. Your answers to the survey will be downloaded only to the researcher's computer and will be password protected. The survey link will be available until August 2018. I would greatly appreciate it if you would complete this at your earliest convenience. If you have any questions, you may contact me at XXXXXX@mail.missouri.edu or XXX-XXX-XXXX, or my advisor, Dr. Wendy Sims, at XXXXX@missouri.edu or XXX-XXX-XXXX. Questions about your rights as a research participant may be addressed to the University of Missouri Institutional Review Board (IRB) at XXX-XXX-XXXX. Thank you very much, Christopher S. Kindle Doctoral Candidate University of Missouri

By clicking the >> button to enter the survey, you are providing your informed consent to participate in this research project. 
Following questions are for demographic purposes only

\section{End of Block: Block 9}

Start of Block: Following questions are for demographic purposes.

Gender:

Female

Male

Other

Prefer Not to Respond

\section{3}

How many years have you been teaching (please use whole numbers and count this year as 1)?

;

Approximately how many students attend the school in which you teach? 
What is your ACDA Region?

(Click link for ACDA Region Map) https://acda.org/ACDA/About/Chapters/ACDA/AboutRoot/Chapters.aspx

Central

Eastern

North Central

Northwestern

Southern

Southwestern

Western

Did you begin the show choir(s) at your school, or was it established when you took over?

Began the Program

Established Program

How many show choirs do you direct in your school?

1

2

3

$4+$ 
For the rest of the items on the questionnaire, please respond based on your mixed varsity level show choir. 
Please indicate to what extent you agree or disagree with the following statements.

\begin{tabular}{|c|c|c|c|}
\hline $\begin{array}{c}\text { Strongly } \\
\text { agree }\end{array}$ & $\begin{array}{c}\text { Somewhat } \\
\text { agree }\end{array}$ & $\begin{array}{l}\text { Neither } \\
\text { agree nor } \\
\text { disagree }\end{array}$ & $\begin{array}{l}\text { Somewhat } \\
\text { disagree }\end{array}$ \\
\hline
\end{tabular}

A main
purpose/role
of the show
choir is for
competitions.

competitions.

A main purpose/role of the show choir is for community outreach.

A main
purpose/role
of the show
choir is to
provide the
students a
chance to
perform a
variety of
musical styles
and
incorporate
multiple
disciplines like
dance, band
and theatre.

The show choir is the main recruitment tool for the choral department.

Show choir allows students to have a wellrounded choral 
experience.

Please identify any other purpose(s) you believe the show choir serves:

\section{End of Block: SECTION 1}

\section{Start of Block: SECTION 2}

The mixed varsity show choir is open to grades:

$9-12$

$10-12$

$11-12$

Other (Please Explain)

The mixed varsity show choir is (choose one):

Separate from the concert choir

Doubles as the concert choir for the whole school year

Doubles as the concert choir for part of the year 
Students are required to participate in concert choir if they wish to participate in show choir.
Yes
No
Other (Please Explain)

Show Choir is (choose one):

A for-credit class that meets during the regular school day

A for-credit class that meets before and/or after school

An extracurricular class that meets during the school day

An extracurricular class that meets before and/or after school

If show choir meets during the day, are there extra rehearsals before or after school?
Frequently
Often
Sometimes
Infrequently
Never
N/A 
Please indicate the approximate percentage each type of show choir music represents in your program (may use 0; numbers should add up to 100):

Stock Charts :

Show Packages:

Custom Arrangements :

Teacher Arrangements :

Other (Please Explain) :

Total :

Who choreographs your show choir? (please check all that apply)

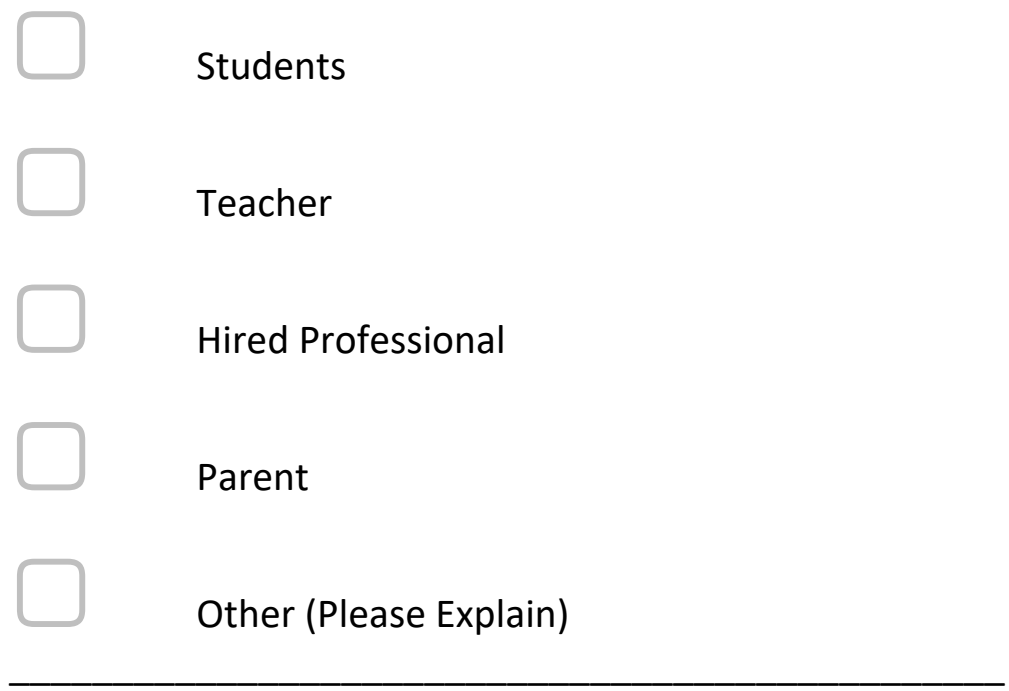

Is a live band part of the show choir?
Yes
No 
Student performers must audition to be part of the show choir band.
Yes
No
N/A

The live band consists of (choose one):

\section{Students Only}

Mostly students (1 or 2 non-student musicians)

Mostly Non-student musicians (1 or 2 student musicians)

Non-students only

Other (Please Explain)

Please indicate to what extent the band rehearses with the singers.

\begin{tabular}{|c|c|c|c|c|c|}
\hline & All Rehearsals & $\begin{array}{c}\text { Most } \\
\text { Rehearsals }\end{array}$ & $\begin{array}{c}\text { Many } \\
\text { Rehearsals }\end{array}$ & $\begin{array}{c}\text { Some } \\
\text { Rehearsals }\end{array}$ & Never \\
\hline $\begin{array}{l}\text { With the } \\
\text { singers } \\
\text { during the } \\
\text { school day }\end{array}$ & & & & & \\
\hline $\begin{array}{l}\text { With the } \\
\text { singers } \\
\text { before } \\
\text { and/or after } \\
\text { school }\end{array}$ & & , & & 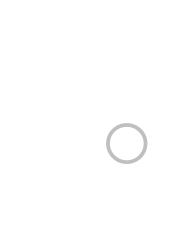 & \\
\hline
\end{tabular}


Please indicate yes/no to the following statements.

\begin{tabular}{|c|c|c|}
\hline & Yes & No \\
\hline $\begin{array}{l}\text { Students must perform a } \\
\text { singing audition to be a part o } \\
\text { the show choir }\end{array}$ & & \\
\hline $\begin{array}{l}\text { Students must perform a } \\
\text { dancing audition to be part of } \\
\text { the show choir }\end{array}$ & & \\
\hline $\begin{array}{l}\text { Each student auditions } \\
\text { individually }\end{array}$ & & \\
\hline $\begin{array}{l}\text { Students audition in groups } \\
\text { such as quartets or larger }\end{array}$ & & \\
\hline $\begin{array}{l}\text { Students audition both } \\
\text { individually and in groups }\end{array}$ & & \\
\hline
\end{tabular}

\section{End of Block: SECTION 3}

Start of Block: SECTION 4

What is the total budget for the show choir per year?

Please indicate the approximate percentage of the show choir budget funded by each entity

(may use 0; numbers should add up to 100):

School/District :

Student membership fee :

Parent Booster Organization :

Business Sponsorship :

Student Fundraisers :

Other (Please Explain) :

Total : 
How much does each student pay to be part of the show choir (please fill in a number, fill in 0 if there is no fee)?

Students have the opportunity to participate in fundraisers to help offset their individual fee.

Yes, participation required

Yes, participation optional

No fundraisers to offset individual fees

No student fees are required

\section{3}

Please indicate the approximate percentage of your budget spent on each category (may use 0; numbers should add up to 100):

Music :

Choreography :

Costumes :

Props :

Travel :

Paid instrumental musicians :

Other (Please Explain) :

Total : 
How many performances are given for each of the following categories during the school year

(please fill in a number, fill in 0 if no performances given for that category)?

Competitions

School

Community

Other (Please Explain)

\section{*}

Considering all of the competitions you attend, indicate the approximate percentage each competition type represents (may use 0; numbers should add up to 100):

High School Sponsored :

College Sponsored :

State Association Sponsored :

Amusement Park Sponsored :

Other (Please Explain) :

Total :

\section{End of Block: SECTION 4}

\section{Start of Block: SECTION 5}

What is the total number of singers in the choral department?

How many singers of each voice part are in the varsity level show choir:

Soprano

Alto

Tenor

Bass 
How many minutes are spent on each type of warm-up before rehearsal (please fill in a number, fill in 0 if no time is spent)?

Physical Mental

Repertoire

Other (Please Explain)

3

Please indicate the approximate percentage of each style of music that is learned/performed by the show choir (may use 0; numbers should add up to 100):

Classical :

Pop :

Rock :

Broadway :

Jazz :

Other (Please Explain) :

Total : 
Please indicate to what extent these items are practiced during the rehearsal.

\begin{tabular}{|c|c|c|c|}
\hline All R & $\begin{array}{c}\text { Most } \\
\text { Rehearsals }\end{array}$ & $\begin{array}{c}\text { Many } \\
\text { Rehearsals }\end{array}$ & $\begin{array}{c}\text { Some } \\
\text { Rehearsals }\end{array}$ \\
\hline
\end{tabular}

Music reading

Vocal
fundamentals

Proper vocal singing

Uniform

vowels

Diction

Pitch and intonation

Proper breath support and breathing

Please indicate to what extent you agree or disagree with the following statements.

\begin{tabular}{|ccccc} 
Strongly & Somewhat & Neither & Somewhat & Strongly \\
agree & agree & $\begin{array}{c}\text { agree nor } \\
\text { disagree }\end{array}$ & $\begin{array}{c}\text { disagree } \\
\text { disagree }\end{array}$
\end{tabular}

\footnotetext{
Different vocal

technique is addressed depending on the song selection.

Beautiful choral tone is the end goal of the show choir(s).
} 
Vocal assessments are administered for proper vocal production.

Frequently

Often

Sometimes

Infrequently

Never

Vocal assessments are administered to check vocal parts.

Frequently

Often

Sometimes

Infrequently

Never

Please describe any other content/goals/objectives covered in your show choir curriculum. 


\section{End of Block: SECTION 5}

\section{Start of Block: SECTION 6}

Please indicate to what extent you agree or disagree with the following statements.

\begin{tabular}{|c|c|c|c|c|c|}
\hline & $\begin{array}{l}\text { Strongly } \\
\text { agree }\end{array}$ & $\begin{array}{l}\text { Somewhat } \\
\text { agree }\end{array}$ & $\begin{array}{l}\text { Neither } \\
\text { agree nor } \\
\text { disagree }\end{array}$ & $\begin{array}{l}\text { Somewhat } \\
\text { disagree }\end{array}$ & $\begin{array}{l}\text { Strongly } \\
\text { disagree }\end{array}$ \\
\hline $\begin{array}{l}\text { Show choirs } \\
\text { are too time } \\
\text { consuming. }\end{array}$ & & & & & \\
\hline $\begin{array}{l}\text { The price of } \\
\text { show choir } \\
\text { results in } \\
\text { students who } \\
\text { are not able to } \\
\text { participate. }\end{array}$ & & & & & \\
\hline $\begin{array}{l}\text { The } \\
\text { choreography } \\
\text { makes it } \\
\text { difficult to } \\
\text { keep the focus } \\
\text { on proper } \\
\text { singing. }\end{array}$ & 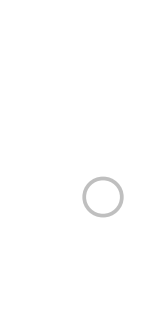 & $\cap$ & & ( & \\
\hline
\end{tabular}

Please describe any drawbacks you have experienced or can see with show choir. 
Please describe any benefits you have experienced or can see with show choir.

Please feel free to include any comments you may wish to make regarding the high school show choir.

\section{End of Block: SECTION 6}

\section{Start of Block: Block 10}

Thank you for taking the time to complete this survey. Please feel free to email me at XXXXXX@mail.missouri.edu if you would like to receive the results.

\section{End of Block: Block 10}




\section{Appendix B}

\section{Institutional Review Board}

190 Galena Hall

University of Missouri-Columbia

Columbia, MO 65201

573-882-3181

irb@missouri.edu

May 01, 2018

Principal Investigator: Christopher Scott Kindle

Department: School of Music

Your Exempt Application to project entitled The Role of the Show Choir in the High School Choral Department was reviewed and approved by the MU Institutional Review Board according to the terms and conditions described below:

$\begin{array}{ll}\text { IRB Project Number } & 2010548 \\ \text { IRB Review Number } & 233982 \\ \text { Initial Application Approval Date } & \text { May 01, 2018 } \\ \text { IRB Expiration Date } & \text { May 01, 2019 } \\ \text { Level of Review } & \text { Exempt } \\ \text { Project Status } & \text { Active - Open to } \\ \text { Exempt Categories } & \text { Enrollment } \\ \text { Risk Level } & \text { 45 CFR 46.101b(2) } \\ \text { Internal Funding } & \text { Minimal Risk } \\ \end{array}$

The principal investigator (PI) is responsible for all aspects and conduct of this study. The PI must comply with the following conditions of the approval:

1. No subjects may be involved in any study procedure prior to the IRB approval date or after the expiration date.

2. All unanticipated problems and deviations must be reported to the IRB within 5 business days.

3. All changes must be IRB approved prior to implementation unless they are intended to reduce immediate risk.

4. All recruitment materials and methods must be approved by the IRB prior to being used.

5. The Annual Exempt Form must be submitted to the IRB for review and approval at least 30 days prior to the project expiration date. If the study is complete, the

Completion/Withdrawal Form may be submitted in lieu of the Annual Exempt Form

6. Maintain all research records for a period of seven years from the project completion date.

7. Utilize all approved research documents located within the attached files section of eCompliance. These documents are highlighted green.

If you are offering subject payments and would like more information about research participant payments, please click here to view the MU Business Policy and Procedure: http://bppm.missouri.edu/chapter2/2_250.html 


\section{Appendix C}

Thank you for choosing to participate in this research project, entitled "The Role of the Show Choir in the High School Choral Department." Please only complete this survey if you are a high school choral director that has a mixed varsity show choir.

The purpose of this study is to contribute to the understanding of what role the show choir plays in the high school choral department. This will include the logistics of show choir programs, the musical and pedagogical aspects, and the benefits and drawbacks to having a show choir program. Findings of this study may be published and presented at professional conferences.

The survey that follows should take approximately 12 minutes to complete. It is unlikely you will experience any risks from participation in this study. Your participation in this research is completely voluntary. Although I hope you will complete the whole survey, you are free to decline to answer any items, as you choose. You may remove yourself from the research study at any point without penalty.

Your responses to the survey items will be completely anonymous, and there will be no way for me to connect survey responses with respondents. Your answers to the survey will be downloaded only to the researcher's computer and will be password protected. The survey link will be available until May 15, 2018. I would greatly appreciate it if you would complete this at your earliest convenience.

If you have any questions, you may contact me at $X X X X X X @$ mail.missouri.edu or XXX-XXX-XXXX, or my advisor, Dr. Wendy Sims, at XXXXX@missouri.edu or $X X X-X X X-X X X X$. Questions about your rights as a research participant may be addressed to the University of Missouri Institutional Review Board (IRB) at XXXXXX-XXXX.

Thank you very much,

Christopher S. Kindle

Doctoral Candidate

University of Missouri

By clicking the >> button to enter the survey, you are providing your informed consent to participate in this research project. 


\section{Appendix D}

Dear Show Choir Director,

If you are a director of a mixed varsity show choir, I hope you will consider participating in my survey. I am a vocal music educator and doctoral candidate at the University of Missouri, working on a research project entitled "The Role of the Show Choir in the High School Choral Department."

The online survey includes questions about the logistics of show choir programs, the musical and pedagogical aspects, and the benefits and drawbacks to having a show choir program. It will take approximately 12 minutes to complete. All survey responses will be completely anonymous, with no way for me to identify respondents.

The results of this national survey are intended to contribute to the understanding of what role the show choir plays in the high school choral department. Findings of this study may be published and presented at professional conferences.

Please feel free to address any questions you may have about this research to me (XXXXXX@mail.missouri.edu). If you know fellow directors who are not a part of this Facebook page and you think would like to participate as well, please feel free to send them my contact information or forward this message to them.

Thank you very much for considering this request,

Christopher Kindle

Ph.D. Candidate

University of Missouri

Columbia, MO

$\underline{\text { XXXXXX@mail.missouri.edu }}$

To participate in this survey study, please click the following link: 


\section{Appendix E}

\section{Please identify any other purpose(s) you believe the show choir serves.}

"Student growth on personal levels"

"Bring students together who would not normally spend time with each other."

"I believe it is a creative outlet for most students. It is something that is challenging yet attainable and rewarding."

"Show choir has also been instrumental in teaching character/life skills. Many of the students at our small charter school are quite shy, come to us after incidents of bullying in their public school, or deal with anxiety. Through our show choir rehearsals they learn to be part of a team, trust the other members, and become more confident in their abilities. Performance has always been secondary to process in my mind. We may not have a lot of trophies, but I am impacting the lives of students daily."

"To create a safe space for students who wouldn't ordinarily find their place in a public school environment."

"Our show choirs also perform standard Choral literature throughout the year. Our choirs sing Rutter, Whitacre, and other challenging literature, in order to make sure they experience good ear training and are exposed to a well-rounded choir experience. Within our show choir songs, we teach the same Bel Canto singing that we do with the standard literature, to achieve a strong correlation for strong training, and to foster lifelong learning."

"Team work and responsibility also they learn how to follow a chain of command. My students learn how to problem solve also."

"It provides a lot of students a place to "fit in" through a culture of acceptance. It also fosters a love for the arts, new friendships, and an appreciation of dedication and hard work."

"With competition comes the invaluable educational experience of traveling. Especially in cases where rural schools are traveling to national competitions in bigger cities and the opposite."

"This show choir had already been established when I began teaching here. I teach Choir as the main subject but the show choir appeals to some students in a very positive way. After 6 years I have finally been able to make sure that the students that are in the show choir are also in a regular school choir. The show choir is finally beginning to be an extension of the choral program. We are singing better as a choir and it is definitely an outlet for so many students that want something extra. I have students that are in the program because of show choir but are a positive influence in the regular concert choir." 
"Teaching proper vocal techniques while using popular music"

"I use it as a way to teach presentation, carrying yourself with maturity and poise, and discipline."

"To help raise students to be well rounded students - and a member of a community that depends on them. To Teach responsibility and accountability."

"Builds a sense of school pride in the choir and in school itself."

"The different style of performance is often a catalyst for pushing limits. The kind of effort required to put on a show choir performance has a level of physical and emotional demand that far exceeds anything else in the choral spectrum."

"Show Choir can serve as a "piece of the pie" in a well-rounded program where choral music is the main pie."

"Recruitment Self-esteem building Teaching good citizenship Team building"

"Teaches students about hard work, team work, and social skills that will aide them long into the future."

"In addition to musical and performance concepts, show choir teaches students valuable skills needed to be a successful employee, well-rounded person and supportive friend. It's an excellent experience for students."

"One step beyond a recruitment tool, it is a way to get kids in the door and then introduce them to other styles of choral singing."

"Teaches students responsibility, get along with others, work as a group, yourself worth is not dependent on what other people think...are just a few things."

"Community building, learning to multitask."

"Show choirs teach students how to be vocally versatile. Properly singing different styles/genres teaches students how to uses different techniques to produce sounds that are appropriate for the style. Traditional choral, pop, musical theatre, a cappella, opera, and vocal jazz are all used in show choir. Whether students pursue a music career as a performer, teacher, therapist, private instructor, etc., having the skills to sing in different styles is very important and will open more doors for them."

"To provide students a tight-knit community within the larger school community in which to belong" 
"Teaches teamwork, mutual respect, performance skills, handling yourself in front of an audience, accelerated musical \& singing levels, fosters self-esteem."

"Builds many other integral skills such as confidence, self-discipline, accountability, working well under pressure, leadership, working in a team, and more."

"There is a huge psycho-social aspect of being in show choir that is similar to that of other team sports. The team atmosphere, group dynamic, goal-setting, winning and losing vs. beating or losing to self, responsibility of team before self, knowing when to lead and when to follow, and a host of other non-music related items that I believe are not only present but absolutely necessary in teaching as you go throughout the year."

"Develops team work - organization skills - leadership skills - learn how to handle success and failure in a public manner - extra time with teaching vocal technique -- pulls together parents - teachers - students - others - to all work toward a goal"

"I believe show choir gives a competitive outlet for students not interested in athletics. It also provides an opportunity for students to network with other individuals with passions that are similar to themselves."

"A competitive show choir program serves many purposes in the 21 st century skills that so many future employers are looking for. These kids have to be dedicated, work hard, be flexible, be willing to look at different ways of doing things, obviously work as a team, work as a group for one mutual goal, just to name a few. It also is probably one of the best classes for incorporating multiple fine arts all in one."

"Social and emotional intelligence. Public speaking, confidence building, etc."

"Purpose to teach future lifetime skills such as teamwork, diversity, perseverance, communication skills, goal setting, and finding the beauty in life."

"It provides the next level of performance than standing and singing. Deeper art form because of dance and acting aspect. Show Choir is a break off of Musical Theatre and Pop/Rock Music along with a break off of Jazz Dance and Street Dance. Students engage in Show Choir because it is the closest performing arts to what they see on TV. Public Relations for the school district, bonds the music department as a whole, similar to a musical."

"Show Choir serves as a "home" for the students involved to feel a sense of belonging, a safe place, and a group of similarly minded students who grow together." 


\section{Appendix F}

\section{Please describe any other content/goals/objectives covered in your show choir curriculum.}

"Since show choir is extra-curricular, I do not view it as heavily with thoughts and planning about content and curriculum as these kids are all in my concert and chamber choir classes during the school day and we are more content/curriculum driven in those courses."

"Dance assessments are also frequent during sc season."

"Because it is a function of my concert choir, we also need to meet state standards. I also assign and assess projects/tests in music history, music careers, music theory, and solo/small group performance."

"Quality performance and entertainment value are of the upmost for our show choir."

"Positive interaction, resolving issues, with all involved - directors, peers, volunteers, parents, band, etc. We also make sure to make sure every student feels like an important part of the program, both vocally and as a person."

"I can't think of anything else."

"Dancing."

"How to look on stage while singing and dancing. How to present yourself on stage."

"Good singing is good singing is good singing. Regardless of the genre or style of the piece. Regardless of the choir singing the music (show choir, concert choir, jazz choir). All choirs are expected to practice proper vocal technique and sing the repertoire chosen in the appropriate fashion for that repertoire and what it represents."

"Covering contest as well as pop music styles"

"Student reflection of performance to plan for future rehearsals. Student involvement in the financial responsibilities of fundraising. Honing student leadership and teamwork."

"Storytelling, facial expressions, body language"

"Performance Excellence"

"Student behavior, how students present themselves daily, academic success (grades are closely monitored), choreography perfection, gratitude, family atmosphere, respect for teachers and parent volunteers." 
"breath management"

"Same goals assessed for the Classical technical training."

"Understanding of emotional connection to selections. Group develops unified mental attitude for the performance." 


\section{Appendix G}

\section{Please describe any drawbacks you have experienced or can see with show choir.}

"It's a great activity"

"Dancing can take away from vocal technique, choreography when executed correctly should not."

"Pride and investment in show choir can/has detracted from pride/investment in Concert Choir class."

"I lose some my top singers who are not able to take both show and concert choir."

"It can be very draining on the director and students who are in multiple activities and multiple choral ensembles and events throughout the year."

"It can become the tail that wags the dog if you let it. I try to keep my kids grounded by working other classical literature simultaneously with our show set, stressing the importance of vocal flexibility and proper technique."

"The extremely high quality and enormous number of performers from several "major" programs in our area sets an unreachable bar for many other schools. This imbalance is not sufficiently addressed by a vague, non-uniform choir/school classification system at local competitions."

"I lose quality talent because currently you're required to be in class choir to be in show choir."

“In rare instances, students don't buy in because we hold our students to high standards of academics, behavior, and responsibility, so instead of rising to our expectations, they quit after a year."

"I haven't seen any drawbacks."

"None"

"As a teacher, just purely the time commitment it takes and managing all the finances."

"Students do Not want to explore traditional choral music."

"It is expensive and hard work for some students to raise money."

"There are no rules in show choir. Sometimes I feel that this is unfair at competitions. You can have props, lights, adults in your band, etc. and those things can really help your performance. If you don't have as much money as other schools that use these things in their show, you are already a step behind." 
"Because it meets during the school day it hurts membership in the concert choirs."

"The time commitment required for excellence. For our students ( $93 \%$ free and reduced lunch) many students look after siblings if from a large family, or work. The time to accomplish their goals can be a challenge."

"There are times when students do not finish the year after show choir and that has been frustrating"

"Only the perception of those who are against it but haven't experienced it."

"Expense. In order to be competitive, there is a certain level of investment in order to obtain quality custom arrangements, secure a choreographer that understands proper singing as it relates to choreography, and to purchase costumes."

"It is hard to compete with schools that have show choir budgets. It puts schools like mine at a disadvantage."

"Ego! Both in students and parents who believe their spot is deserved not earned."

"Proper Vocal technique is complicated by the student's familiarity with stylistic characteristics of typical show choir music. Not impossible but definitely complicated."

"Show Choir can become time consuming, and it can be difficult to convince kids to be involved in the concert choirs."

"My kids are the same that participate in sports, academics, 4-H, student councilsometimes they are really busy. I don't have time to train their families how important developing relationships with family member is."

"Students who do not make show choir sometimes feel like they are not "good enough" singers, but some of my better singers are in concert choirs."

"While only $40 \%$ of my teaching load, it requires $80 \%$ or more of my "administrative" energies. Without consistent, conscious efforts to build culture otherwise, show choir can become the "tail that wags the dog" in the choral program- parents and students believe that show choir is the most important component. It requires constant education and reeducation into communicating that concert choir and good musical foundations are the core of the choral program!"

"Does seem to focus less on vocal technique. All new to me."

"With great success--championships--comes the need to keep up the level of the program. This eventually leads to long hours. I work 65-70 hours a week between my classes and the competition show choir." 
"Directors have to learn how to use it as a tool to build their program - if it is the only thing in their choral program, they are missing out on a well-rounded program including better trained singers."

"If show choir is the only choral experience kids are getting while in high school, they are missing out on the differentiation of the choral tone spectrum. While you may have the ability, from year to year, to have differentiated genres in a show, one misses out on many other genres like Renaissance, Jazz and other varied musical experiences."

"Cost -- and where the money actually goes"

"If students are not required to be in the curricular choir, the show choir becomes the emphasis, and detracts from the curricular program."

"Probably just the cost to the parent group. It's getting REALLY expensive to have a competitive show choir. Not sure the price compares with the outcome and what the kids are getting out of it anymore. I didn't used to feel this way, but it's getting really expensive. Some programs I know have had to eliminate that part of their programs."

"The students enjoy it more than the traditional ensemble"

"Gossip, exhaustion, grades/other activities suffer due to time consuming."

"Balance is the key! As the educator it is your job to keep a balance on priorities and what is best for your school program and students. I have seen other programs lose focus of the big picture. Teaching music and young adults for the future!"

"Students getting worn too thin being involved in so much. Small Town atmosphere, some students who are not even in the program do not like that the show choir has an attention from the community similar to the sports program (sad, but it's true). Students who are involved get made fun of for being a part of it...looked upon as weaker than the sports program. (sad, but we get through it)"

"It is the teacher's responsibility to keep the focus on choral production. Students often lack the long-range vision." 


\section{Appendix H}

\section{Please describe any benefits you have experienced or can see with show choir.}

"Student growth including personal skills"

"Students emerge from the show choir as leaders and are a stringer team than when they started."

"We have recruited several students from our performances and by current members dragging friends in to try it out."

"Helps students to become more comfortable on stage."

"I love show choir; it is how I became to love choral music and I try to provide that same opportunity and experience to my students."

"Discipline, endurance, challenges to meet, goal setting, team skills"

"Physical health improvement in students. Community support of student endeavors. Increased enrollment in Vocal Music. A place for many students to feel a sense of belonging. Accountability for grades in all classes."

"Musically, I feel show choirs produce better performers. They are more skilled in making an emotional connection to the music and shrug that wig an audience.

Additionally, as mentioned before, I've seen significant gains in social skills and confidence in my students as they build rapport, trust, and accountability with their section and choir."

"The development of important "soft-skills" is huge! Students may never sing/perform again after HS, but they will be teammates, workers, leaders, citizens, \& people forever."

"Again, that students find 'their place' in the world."

"We are able to introduce excellent standard literature for our singers for Christmas and once show choir season is ended. We continue to teach technique and sight reading to strengthen singers' grasp of vocal performance and adding emotional aspects to every performance."

"Students make lifelong friends and memories that will last a lifetime. They also learn other valuable skills to use for the rest of their lives (not just singing and dancing)."

"Musically challenging, teaches teamwork, cooperative learning, discipline and time management!" 
"It's a great recruiting tool to get students into the concert choirs. We also travel to many different places and those experiences are more educational than anything they can get in a classroom."

"Confidence"

"Positive relationships b/w students. Strong true friendships. Confidence builder. Creative outlet."

"Show choir has helped many of my students find a positive way of expressing themselves."

"Self-confidence, people skills, organization, stamina, good health, team work, lifelong friendships, it has helped students in career choices, leadership skills"

"The individual growth per student (as a musician, performer, and human)."

“Teamwork Team-building Self-confidence Growth mindset Collaborative Goal Setting"

"The community that grows out of show choir is fantastic. The pride the students learn from really performing their show and getting such amazing feedback is unlike anything they will get later in life. these students can be counted on to finish the jobs."

"My singers have a better understanding of what their voices and bodies can achieve and the story-telling and emotional connection they have gained from performing in show choir work their way in to the classroom choral experience as well."

"Students love to perform and the culture that results is one of camaraderie and support unlike anything I've seen in other competition activities."

"It teaches so many valuable things: coordination, teamwork, acceptance, humility, self esteem... I could go on!"

"Great growth in musicians' ability to adapt or improve after hearing what judges/clinicians have to offer. Self-reflection improves focus. Competitive nature brings out unique and often out of the box experiences that students in general choirs will never understand or experience."

"Show choir prepares a complete performer/entertainer."

"I have seen so many kids start the year shy and withdrawn and end the year confident and outgoing. It gives kids a home and a family at school, which for many kids is more important than any subject matter being taught. It teaches kids how to work hard and to work well with others, gives many kids the chance to develop leadership skills, teaches them independence, and many other skills that help them become productive members of society." 
"Builds character, sets high expectations, develops leadership and ownership, teaches responsibility, is often something most parents appreciate and don't get "bored" with watching"

"The students learn how to become well rounded performers and build a stamina that will aid them in any performance opportunities they take in the future. They also learn punctuality, humility, teamwork on an immense level, and a myriad of other essential tools that will take them far in life."

"Ability to problem solve, to work together as a team, to get along with others, to follow student leadership, to develop appropriate leadership skills, to overcome difficulties, to become stronger performers, to be a part of a "family", to develop school spirit via pride in the music program, to develop a deeper love for music and a willingness to learn a greater variety of styles of music."

"Huge recruitment tool. I can introduce traditional choral pieces to them and help them discover a love for that music and singing style."

"It challenges students to pursue excellence over the course of a long period of time. In an instant gratification world, the "payoff" from choreography camp in the summer to competition season in the winter is a long time coming! Also, it provides students a medium through which to become deeply invested and find significant artistic expression."

"I love the pride students have in their progress."

"National ranking and reputation, seen as an excellent show choir clinician, called upon to arrange music for competitive show choirs across the country."

"There are so many benefits - honestly, too many to list. From self-confidence and personal skills in life to performance skills."

"As I stated previously, these are too many to count. I will also add, though, that show choir gives kids the opportunity to let them themselves be vulnerable with their peers in public performances. From confidence, to personal exploration, to hard work, to proper singing and breathing, there are a thousand positives by participating in show choir. You might be able to make the argument that team sports and activities like drama, dance, team robotics and cheer can give you many of the same life-building experiences through a different medium."

"Bonding between the students is greater"

"I have seen numbers in my program go up because of show choir."

"All the benefits outweigh the negatives. It truly is a wonderful way to represent and work on so many different areas of the fine arts. The kids are pushed to work hard on 
vocal music, something they might otherwise toss aside. They are sitting in a critique session on a Saturday morning somewhere, and I often think "in what other scenario would a kid willingly give up a Saturday to learn how to become a better singer and performer"... It creates amazing, life long memories. It truly is an important part of our music program."

"The competitions and events have created a family dynamic within the group"

"Preparation for students to audition and perform in other musical settings (theme parks, musical theater, barbershop, etc.)"

"Social/emotional intelligence greatly increases. Public awareness and ability to communicate greatly increases."

"The teamwork of bringing all types of students into the classroom for a common goal. The empathy that is taught through this is often challenging but amazing to watch!"

"More students can gain CONFIDENCE not just the sports students. Chance to promote the school in a positive atmosphere to community (giving back). Public relations!!! Big Time. Support from so many new people who appreciate the time you give to the student's successes! WIN, WIN situations!”

"Show Choir in its right place fosters a strong music community of singers as well as in their community." 


\section{Appendix I}

\section{Please feel free to include any comments you may wish to make regarding the high school show choir.}

"I wish we had a standardized rubric for show choirs"

"I wish there was a consistent governing body over judges training (similar to marching band/winter guard competitions). In our short time of competing, we've seen very different results at each competition, sometimes completely mystifying to myself and my kids."

"It not only attracts the best singers in our school, it's the place all of our students come to feel safe. We recently had a lockdown as a result of threats made to the school, and much of our choir and show choir students came to the choir classroom to feel safe, and to help keep calm. Show choir is life."

"I love it!!!"

"While it can be time consuming, it has always been worth it in the end. I always say that a show choir is like a marching. A good Marching band normally means they have an even better Concert band. Same for show choirs. I believe students are more wellrounded. We had a performer in Branson Missouri say once that he wishes he would have had show choir in high school - as it would have better prepared him for his actual performance career."

"It is a great art form and activity to really push kids to be better than they thought they could be."

"I understand that some people think show choir is low brow. I think it can be used as a great tool to get kids in the door. Once they buy and you can teach them any kind of music. It's a great way to help kids understand how great music can be... All kinds of music!"

"At my school, being a member of show choir is the penultimate achievement for vocal musicians. And I am finding that our instrumentalists are also clamoring for spots in our show choir combo. The life of a show choir director is harder than any other job I've ever had, but also far more rewarding!"

"Most show choir kids are still taught the same music and vocal fundamentals that are taught in concert choirs."

"The show choir is what puts our school on the map and brings tons of positive attention to the arts in general. Our students go on to excel in various fields and become leaders in said fields with the tools they've learned in show choir." 
"Show choir is a great outlet for students who need more movement in class, and I have witnessed it helping students who struggle in school and personal lives. Traditional choir does this, too, however, music is like every other art form and evolves over time and as artists, it is important to sing traditional repertoire, and know where all our music came from, but there is still value in modern songs and musical skills to be learned through this repertoire and style of choir."

"For all its frustrations as a director, there can be a lot of good that comes from a quality, balanced show choir program."

"I personally think competitive show choir has seen its best days and is on a downward slide. Participation levels are dropping, associated websites see far less traffic than 10 years ago, sponsored competitions are seeing attendance numbers drop, fundraisers produce fewer dollars. There are too many other things now to claim a student's time and devotion (after school jobs, for one). Even athletic teams say fewer students are involved today. This is largely due to the cost of participation and the time commitment necessary for excellence."

"Well-worth the time, has its place in absolutely any program if you set it up correctly. The idea that it is the tail that wags the dog is only true if you allow it to be in the curriculum."

"Mixed feelings -- I think it is a "young person/director" sport. I am coming from the perspective of a person who is at the end of his teaching career. This element has turned into a business. While I admit that I do benefit from that (I frequently judge

competitions), I still am befuddled by the amount of money that has to be raised to put in a gas tank for a bus to attend a competition. In my situation, the choreographer, the costume person, the arrangers, all get paid more than I do to direct this group. However, I put in the most time of anyone. This is what is driving me away"

"I believe that show choir can be an incredible out reach for your school district! Being in the community with young people performing for little children to senior citizens and seeing the response on both sides are rewarding and important in the society we live in."

"You make Show Choir what you choose to put into it. Many directors who do it, truly LOVE IT! They are willing to spend countless hours most times without pay because they were given those type of experiences for yourself. IT is addicting! Developing new show concepts and themes. GREAT FUN! Students get really into it if you get into it as well. Unbelievably supported by the community but you must keep the students in check with grades and behavior because someone is always watching. You can do Show Choir at such small levels as well. I fully support that too. but you will have those extremists. I wish the Classical Community wouldn't be so negative towards Show Choir-jealously doesn't look good on anybody. I am not forcing directors to do Show Choir. It deserves to have its place in the vocal community of Classical Singing, Musicals, Jazz, because it has sustained 50 years! this is the birth year! as far as I know...it was called Swing Choir 
but, it was singing and dancing to music for a show type atmosphere. I was a part of the KIDS from Wisconsin it started in 1968-69! Thank you...this was fun!"

"Show Choir addresses most of the needs of a high school student. I would never teach the group only show choir material." 


\section{VITA}

Christopher S. Kindle attended Northwest Missouri State University, earning a Bachelor of Science in Education degree with an emphasis in Vocal Music Education in 2005. Immediately after graduating he went back to Northwest Missouri State University as a graduate assistant in the music department and received a Master of Science in Education with an emphasis in Vocal Music Education in 2007. Mr. Kindle taught for eight years in public schools in Missouri. He taught secondary choral and general music for seven years and elementary K-5 for one year.

Mr. Kindle will complete a Doctor of Philosophy in Music Education in 2019, from the University of Missouri in Columbia, Missouri. While working on his doctorate he was a graduate assistant teaching courses and supervising music student teachers. Courses he taught included music for children section for elementary education majors, and for early childhood education majors, music student teaching seminar and basic musicianship.

He is an active guest conductor, adjudicator, clinician and choreographer for many choirs and show choirs across the states. He presented an investigation as a poster presentation for the Missouri Music Educators Association state conference, and he has given a presentation on show choir at the state conference of the Missouri Choral Director's Association.

Mr. Kindle plans to continue his involvement in public school and university settings, focusing on aspects of choral music, including concert and show choirs. 